УДК 342.9

DOI https://doi.org/10.32837/apdp.v0i83.124

А. А. Литвиненко

\title{
ЗАХИСТ ПЕРСОНАЛЬНИХ ДАНИХ У СФЕРІ МЕДИЧНОЇ ТАСМНИЦІ: ІСТОРИЧНА ТА СУЧАСНА ПРАКТИКА СУДІВ США, ЄВРОПЕЙСЬКОГО СУДУ 3 ПРАВ ЛЮДИНИ ТА ДЕЯКИХ КРАЇН КОНТИНЕНТАЛЬНОЇ ЄВРОПИ
}

Постановка проблеми. «Цікавий факт, що існує так мало рішень судів стосовно обов'язку тримати у секреті справи покупця чи клієнта як банками, так і адвокатами чи лікарями. Відсутність прецеденту, вочевидь, певним чином завдячує компетентності британських професіоналів, які практично не дали шансу для такої дискусії...», - так заявив суддя Томас Е. Скраттон із Відділення Королівської Лави (King's Bench Division) у справі стосовно розголошення банківської таємниці 1924 p., Tournier v. National Provincial and Union Bank of England, а в наші дні хрестоматійній справі з захисту персональних даних у сфері професійних таємниць ${ }^{1}$.

Суддя Скраттон був однозначно правий: практика судів англо-саксонської правової сім’ї щодо відповідальності за розголошення професійних таємниць (куди, власне, входить і медична таємниця), була незначною на момент першої половини 20 століття. О. Гоппер (1973) у своїй роботі щодо довірених обов'язків лікарів (fiduciary duty of the physician) писав наступне: «Це питання [порушення медичної таємниці] настільки рідко ставало предметів позовів, що правова позиція [стосовно цього] є далекою від ясності, однак права пацієнтів на практиці досить добре захищені професійною етикою» [19, с. 74]. Хоппер писав це в контексті англо-саксонського права, де справи можна «перерахувати на пальцях однієї руки» [19, с. 75].

Деніел Шуман (1985), один із дослідників медичної таємниці в історичному контексті практики судів Англії, писав, що майже цілковита, крім разових випадків, відсутність таких справ (хоча б стосовно допустимості доказів на основі свідчень лікарів), пояснюється тим, що в більш давні часи медицина, вочевидь, не була надійним джерелом доказів, і серед тогочасних прокурорів не було однакового розуміння, чи слід примушувати лікарів свідчити; ще однією причиною є більш прозаїчна: справи могли «загубитися в історії» [21, с. 672]. Однак, як виявляється, «загубилися» далеко не всі, а історія поняття «медичної таємниці» в практиці судів є довгою та цікавою. Також було опрацьовано й «виключення з правил», які надають право лікарям розголошувати медичну таємницю, що проявилося в практиці судів США з початку ХХ століття і триває досі.

Аналіз останніх досліджень і публікацій. Аспектами вивчення питання цивільної та кримінальної відповідальності щодо розголошення медичних таємниць

1 Див. справу Tournier v. National Provincial and Union Bank of England, [1924] 1 K. В. 461, 479. Оригінальна цитата судді Томаса Е. Скраттона англійською: "It is curious that there is so little authority as to the duty to keep customer' or clients' affairs secret, either by banks, counsel, solicitors or doctors. The absence of authority appears to be greatly to the credit of English professional men, who have given so little excuse for its discussion".

(ㄷ) А. А. Литвиненко, 2019 
займалися юристи-практики та науковці ще з середини XIX століття, акцентуацію на практиці судів із цього питання ставили не всі. До того ж, медична таємниця довго не була окремим об’єктом дослідження, тому в більшості ранніх робіт едична таємниця досліджувалася в рамках робіт із медичного права та недбалості в медичному праві. До робіт, в яких досліджувалася або хоча б згадувалася проблематика медичної таємниці більш раннього періоду, можна віднести роботу адвоката А. Требуше (1834) [1, с. 273-286] з теоретичних та практичних аспектів медичного права у Франції XVIII-XIX століття, робота Шарля Муте стосовно теорії і практики судів із професійних таємниць (1870) [2, с. 248-256], книга 3 медичного права Дж. Цііно (1882) [3, с. 21-22], сюди з можна віднести нотатки ${ }^{2}$ французьких адвокатів і науковців М. Віллея та М. Тенона у справах Уателета ${ }^{3}$ 1885 та 1886 років; підрозділи Енциклопедї Британського та Алериканського Права (1892) [4, с. 148-151], дві книги франиузького професора з медичного права, Поля Бруарделя (1887 і 1898 ) щодо цивільної та крилінальної відповідальності за медичну халатність [5, с. 19-і далі] [6, с. 62-і далі], книга франиузького юриста А. Фазелбата (1903) [7, с. 38-43], доповідь Д. Гранжу (1906) стосовно аспекту дерогаиї медичних таєлниць в силу обов'язку лікарів повідолляти органи влади стосовно епіделій [8, с. 16-33], книга італійського юриста А. Луіджі, присвячена закону щодо функиіонування психоневродиспансерів у Iталії (1907) [X, с. 62-66], робота відомого нілецького психіатра А. Молля з медичної етики (1907) [10, c. 90-105].

Серед авторів середини $і$ кіния XX століття, які досліджували питання медичної таємниці, в англо-саксонській систелі права можна виокремити К. Де Вітma (1953 та 1959) [11, с. 19-23] [13, с. 492-495], С. Фрідмена (1954) [12, с. 11], Р. Данслора (1959) [14, с. 463-466], Р. Болдвіна [15, с. 182-185], Д. Вейвера (1966) [16, с.66-70, 74-78], Ч. Рьодерсхайлера (1967) [17, с.103-115], У.К.Бернфельда (1972) [18, с.12-16] О. Гоппера (1973) [19, с. 75-76], А. Сел'юелca (1980) [20. с. 60-64], Д. Шумана (1985) [21, с. 667-672, 678-681], Е. Дойча (1992) [22, с. 170-175], А. Макларена (1993) [23, с. 137-140], Л. Уеллера (1993) [24, c. 187].

Також можна виокремити як вінтажні, так $і$ сучасні роботи з питання права на анонімні пологи - практично «загублений в історї̈ концепт, що походить із права Франиї та Бельгї (який, однак, не знайшов ніякого схвалення ані в законодавстві, ані в прецедентнолу праві ${ }^{4}$ ). Вперше до питання иього ас-

\footnotetext{
${ }^{2}$ У збірниках прецедентного права Франції з початку 19 століття існує практика друку тексту рішення суду разом з приміткою, яка розкриває деякі подробиці справи, наводить справи з судів інших міст Франції та надає опис доктрини, на основі якої суд виніс своє рішення. Автором примітки переважно є практикуючий юрист або спеціально запрошений дослідник чи викладач із права.

${ }^{3}$ Під нею маються на увазі процеси Watelet et Dallet, gerant du journal le Matin, Cour d'Appel de Paris, 5 mai 1885, Sirey 1885 I 347, 348 та Min. Publ.c. Watelet et Dallet, Cour de Cass., Cham. crim., 19 decembre 1885, Dall. Per. 1886 I 347, 348.

${ }^{4}$ Min. Publ c. L.. et S., Trib. Corr. De Gand, 28 juin 1856, B.J.1856.998, 999-1002; $1005-1008$.
} 
пекту звертається А. Требуше (1834) [1, с. 277-281], згодом - Муте (1870) [2, c. 248-256]. До сучасних авторів можна віднести роботи Л. Пасьона (1983) [25, c. 478-492], Е. Крейн (1986) [26, c.647], М. Іакуб (2004) [27, c. 45-52].

Автор статті досліджував проблему медичних таємниць у практииі судів англо-саксонської системи права (переважно Англія та США) і займався категоризацією тих випадків, в яких розголошення медичної таємнииі є обов'язком лікаря відповідно до законодавства та практики судів різних штатів США [28, c. 197-199, 202].

Метою статті $є$ аналіз історичної та сучасної практики судів деяких країн світу та Європейського Суду з прав людини у справах щодо розголошення медичної таємниці з метою досягнення розуміння ії еволюції та правил вирішення судами таких справ. Окремими аспектами дослідження поставлено опрацювання визначення «даних про стан здоров'я» та авторська розробка концепції «права на анонімні пологи», яке надає біологічним батькам дитини право залишатися анонімними, що розглянуто як у його історичному аспекті (право Франції та Бельгії), так і в сучасній практиці ЄСПЛ, США та Італії (зокрема, і в якості імплементації рішення ЄСПЛ по справі Godelli v. Italy).

\section{Виклад основного матеріалу дослідження.}

\section{Поняття "дані про стан здоров'я"}

Що слід розуміти під інформацією, яка мається на увазі під поняттям «медична таємниця», вдало сформулювали французькі суди понад сотню років тому: так, цивільний суд м. неї підпадає етіологія захворювання пацієнта, обставини, через які виникло це захворювання, його перебіг, лікування пацієнта та його результат ${ }^{6}$ - власне, так тоді суд намагався виокремити, що має, а що не має право лікар розголошувати у суді в якості свідка у цивільному процесі. Однак, чи можна віднести до таких даних, до прикладу, рентгенівські знімки? Вочевидь, можна, хоча судами це питання підіймалося рідко. Так, Верховний Суд шт. Мічиган (1935р.), в McGarry v. J.A. Mercier Со зіткнувся з такою справою: залізнична компанія відмовилася оплачувати йому лікування свого працівника, його клієнта, вимагаючи від нього не тільки надати відомості про пацієнта, а й надати рентгенівські знімки. Суд у рішенні ствердив, що попри «нечитабельність» для непрофесіонала, рентген є вагомою частиною «клінічних записів» пацієнта для лікаря (очевидно, що маючи відповідні знання, він може їх ідентифікувати); враховуючи, що рентген є власністю лікаря (а в багатьох штатах США як лікарні, так і лікарі володіють майновими правами у даних

5 “Tribunal civil” - суд першої інстанції у Франції, до предметної юрисдикції якого входять винятково цивільні справи. Напротивагу йому, корекційний суд (фр. Tribunal correctionnel, скорочення в збірниках прецедентнтого права "Trib. corr.") - суд першої інстанції у Франції, до предметної юрисдикції якого входять кримінальні справи. Щоправда, злочини великої тяжкості до неї не входять, що є в компетенції Cour d'Assises. Апеляція по його рішенню йде до міського апеляційного суду (Cour d'Appel). Корекційний суд у Франції виносить рішення (вироки) по справах, де злочин скоїв повнолітній - предметну юрисдикцію щодо справ, в яких злочин скоїв неповнолітній, має "Tribunal correctionnel de mineurs".

${ }^{6}$ Dame Pellerin c. B. et. F., Trib. civ. de Rennes, 12 juin 1903, Dall. Per. 1905 I 321, 321-322. 
пацієнтів ${ }^{7}$ - тою ж мірою, і в Англії ${ }^{8}$ Німеччині ${ }^{9}$ ) та факт того, що лікар надав підприємству звіт щодо лікування працівника, суд вирішив на користь позивача ${ }^{10}$. Підсумувати це можна влучним твердженням Конституційного Суду Колумбії (1996) у справі Arroyo, що до цих даних належить уся інформація щодо стану здоров'я пацієнта (позивача), яка знаходиться в його медичній історії, та висновки, що походять 3 неї11.

Серед «медичних персональних даних» виділяється ряд категорій даних, що за своєю конфіденційністю навіть вище, ніж просто історія хвороби і діагноз пацієнта. Так, в Англії такими, в першу чергу, є дані неповнолітніх, всиновлених чи тих, які перебували під опікою муніципальних органів влади (в сиротинцях, що знаходилися на її утриманні), є строго конфіденційними і позапроцесуально розголошуватися заборонялися ${ }^{12}$. Так, наприклад, у одній із таких справ (“ $D$ ”, 1970) біологічна матір не змогла навіть через суд добитися інформації щодо всиновлення іï дітей, яких вона колись залишила в дитбудинку, а пізніше виявила бажання прийняти їх знову ${ }^{13}$.

Аналогічно, не зміг позивач добитися доступу до даних про свій стан здоров'я, перебуваючи на утриманні різних дитбудинків, у справі Gaskin v. Liverpool City Council: думаючи, що він може подати позов про халатність стосовно власного лікування, внаслідок якого, за його переконанням, у нього розвинувся ряд психічних розладів, що в кінцевому результаті призвели до безробіття; тому позивач безуспішно судився з ліверпульськими органами місцевої влади. Суд вирішив, що суспільний інтерес вимагає утримання даних «під замком» ${ }^{14}$. Власне, ця справа стала приводом для його позову до Європейського суду з прав людини ${ }^{15}$, де він успішно виграв його [X, с. 202].

В деяких штатах США дані щодо психіатричного стану здоров'я, на думку судів, мають настільки високий рівень конфіденційності, що ці записи забороняли витребувати за допомогою повістки в суд (subpoena): таке рішення прийняв Верховний Суд штату Пеннсільванія у справі «В» 1978 p. ${ }^{16}$. В той же час, Федеральний апеляційний суд дев'ятого округу у справі Caesar v. Mountanos 1978 р. прийняв цілком протилежне рішення ${ }^{17}$. В Канаді Верховний Суд в справі Дайлента заборонив використання аналізу крові в якості доказів сторони обвинувачення без згоди

${ }^{7}$ In Re June 1979 Allegheny Cty. Gr. Jury, 415 A. 2d 73, 76-78 (1980).

${ }^{8}$ R. v. Mid Glamorgan Family Health Services Authority \& Another / Ex Parte Martin, [1995] 1 W.L.R. 110, 116; 119-120.

${ }^{9}$ Див. рішення Верховного Суду Німеччини, $B G H, 23.11 .1982$; VIZR 222/79, параграф 16.

${ }^{10}$ McGarry v. J.A. Mercier Co., 272 Mich. 501, 504-505 (Mich. 1935).

${ }^{11}$ Corte Constitucional, Sentencia C-264/96, Exp. N. D-1139 (Re: Jaime Alberto Miranda Arroyo).

${ }^{12}$ Див. W.F.S. Hawkins, Practice Direction (Adoption: Disclosure of Confidential Information), [1968] 1 W.L.R. 373.

${ }^{13}$ In Re D (Infants) [1970]1 W.L.R. 599, 600-602.

${ }^{14}$ Gaskin v. Liverpool City Council, [1980] 1 W.L.R. 1549, 1552-1553 [думка судді Деннінга].

${ }^{15}$ Gaskin v. United Kingdom, (1989) 12 E.H.R.R. 36.

${ }^{16}$ In Re B, 394 A. 2d 419, 425-426 (1978).

${ }^{17}$ Ceasar v. Mountanos, 564 F2d. 1064, 1068-1069 (1978). 
відповідача ${ }^{18}$. У справі Планта щодо неписаних персональних даних Верховний Суд Канади зарахував і відбитки пальців ${ }^{19}$. Такими ж «особливими» є дані про ВІЛ-статус позивача, на захист яких деякі штати США приймали статути ${ }^{20}$. Щоправда, суди деяких штатів зобов'язували лікарні надавати списки донорів крові у справах щодо медичної халатності, де позивач був заражений ВІЛ-інфекцією чи іншою хворобою під час переливання крові ${ }^{21}$; в інших випадках - у цивільних позовах щодо відшкодування збитків за смерть пацієнта, (так званих "wrongful death suit”) ${ }^{22}$. В рішенні по справі I v. Finland, Свропейський суд з прав людини заявив, що повага до конфіденційності даних пацієнта «...є одним із найважливіших принципів правових систем усіх країн-підписантів Свропейської Конвенції з прав людини», наголосивши, що особливу увагу слід приділити захисту конфіденційності інформації стосовно ВІЛ-статусу позивача, забезпечивши якісний правовий механізм для її забезпечення ${ }^{23}$.

Європейський суд з прав людини не надавав конкретного визначення, що охоплює поняття «даних про стан здоров'я», хоча в справі Marper v. United Kindgom підтвердив, що дані ДНК необхідно розглядати як «персональні дані», дарма що вони не є записаними на типових носіях, і належно обробити їх може лише спеціальна машина ${ }^{24}$. Якщо інформація, отримана, до прикладу, з аналізу крові, перенесена на звичайний папір чи внесена у комп'ютер, вона становить таку ж інформацію про стан здоров'я, як і будь-які інші медичні дані в картці пацієнта ${ }^{25}$.

У справі [щодо допустимості розгляду позову] Van der Velden v. The Netherlands ЄСПЛ не раз згадує, що відбитки пальців позивача перебувають у національному ДНК-банку даних Нідерландів, який, враховуючи час рішення суду (2006 р.), очевидно, що є базою даних на електронному носії, де спеціалісти, маючи відповідну апаратуру, могли б ідентифікувати позивача за ними ${ }^{26}$. Якщо згадати більш стару практику ЄСПЛ, наприклад, справу Gaskin v.United Kindgom, то в ній суд чітко відносить дані позивача щодо його стану здоров' я до «приватного та сімейного життя» ${ }^{27}$.

У справі $Z v$. Finland, де Європейський суд визначав, наскільки є допустимими свідчення лікаря стосовно ВІЛ-позитивного статусу та використання цих даних в якості доказів на кримінальному процесі, то документи стосовного аналізів на ВІЛ фігурували разом з іншими медичними даними, а отже, і вони також можуть рахуватися даними про стан здоров' ${ }^{28}$.

\footnotetext{
${ }^{18} R$ v. Dyment, [1988] 2 SCR 417, 436-440.

${ }^{19}$ Robert S. Plant v. Queen, [1993] 3 R.S.C. 281, 291-296.

${ }^{20}$ Doe v. Roe, 155 Misc.2d 392, 404-409; 588 N.Y.S.2d 236, 244-246 (1992).

${ }^{21}$ Boutte v. Blood Systems Ltd, 127 F.R.D. 122, 125-126 (1987); Stenger v. Lehigh Valley Hospital Center, 609 A. 2d 796, 803 (1992).

${ }_{22}$ Tarrant County District Hospital v. Hughes, 734 South Western Rptr. 2d 675, 678-680 (Tex. App. - Fort Worth 1987).

${ }^{23}$ I v. Finland, [2008] ECHR 623, параграф 38.

${ }^{24} S$ \& Marper v. United Kindgom, [2008] ECHR 1581, параграф 63-65; 70-74.

${ }^{25}$ Див. $R$ v. Christie Ann Culotta, 2018 ONCA 665 (Апеляційний суд провінції Онтаріо, Канада), параграф 13-15.

${ }^{26}$ H.J. Van Der Velden v. The Netherlands, [2006] ECHR 1174, Sect. A.; B.

${ }^{27}$ Gaskin v. United Kindgom, [1989] ECHR 13, параграф 34-37.

${ }^{28} Z$ v. Finland, (1997) 25 EHRR 371, параграф 36-57.
} 
У більш ранніх справах Франції іноді фігурує вираз «депозитарію» медичної таємниці, тобто особі, якій довірили медичну таємницю ${ }^{29}$, і яка несе (в контексті Франції - кримінальну, Англії або США - деліктну) відповідальність у разі iï розголошення. В рішенні по справі Берінгера (1991р.), Верховний Суд штату Нью-Джерсі (обставини цієї справи багато в чому нагадують справу I v. Finland у ЄСПЛ) зазначив, що обов'язок збереження медичної таємниці лежить не тільки на лікареві чи іншому персоналі, а й на самій установі (лікарня, клініка), в якій проходить лікування пацієнт ${ }^{30}$.

\section{Історія поняття "медична таємниця" у практиці судів XIX - XX століття. Континентальне право}

У державах континентального права, таких як Франція, Німеччина, Італія, Іспанія, Чилі, Аргентина та ряді інших країн, розголошення медичної таємниці є злочином невеликої тяжкості. Враховуючи наявну практику французьких судів XIX - XX століть, обвинувачувані, як правило, відбувалися штрафом ${ }^{31}$ та рідко коли отримували ув'язнення, хоча юрист А. Фазембат стверджував, що вироки з ув'язненням все ж існували [7, с. 48-53].

У Німеччині у XIX і першій половині XX століття санкцією за позапроцесуальне розголошення медичної таємниці був штраф у 1500 рейхсмарок чи ув'язнення до трьох місяців відповідно до ст. 300 StGB [10, с. 90-91] (в наші дні - ст. 203 $\mathrm{StGB}^{32}$ ). На практиці вони могли бути значно меншими, про що свідчать дві справи, описані нижче ${ }^{33}$. Що цікаво, штраф за розголошення медичної таємниці в сучасній Франції (ст. 226-13) КК Франції (1994-наші дні), як згадано у рішенні ЄСПЛ по справі Societe Plon v. France, становить 15 тисяч євро ${ }^{34}$.

Франція. Франція є країною, у якій практика судів щодо розголошення медичної таємниці є найбільш ранньою та досі однією з найбільш розвинутих у Європі; має немалий спектр справ як із питань допустимості свідчень щодо стану здоров'я пацієнта, так і щодо позапроцесуальних розголошень, починаючи з раннього XIX століття. Автор наведить узагальнення практики судів та розглядає найцікавіші справи з обох аспектів. Правовою підставою для кримінальної відповідальності є ст. 378 Кримінального кодексу Франції (прийнята в 1810 р.), і практика судів виходить безпосередньо з неї. Виникає питання - чи існувало ще щось до неї? Відомостей про це збереглося вкрай мало, однак вони є. Требуше, згадуючи донаполеонівські часи, писав, що до прийняття Кодексу Наполеона, ніякого законодавства з цього приводу не існувало, хоча парламенти (які у добу монархічної Франції виконували і роль судів) різних міст Франції прийняли щонайменше три таких рішення у 1599, 1600 та 1747 роках (два з цих рішень наводяться Луратом, генеральним прокурором

${ }^{29}$ Dame Pellerin c. B. et. F., Trib. civ. de Rennes, 12 juin 1903, Dall. Per. 1905 I 321, 321322.

${ }^{30}$ Estate of Behringer v. Medical Center, 249 N.J. Super. 597, 632 (1991). II 128.

${ }^{31}$ Див. наприклад, справу В... с. X..., Cour de Appel de Besancon, 22 mai 1888, Sirey 1888

${ }^{32} \mathrm{StGB}=$ Strafgesetzbuch (укр. Кримінальний кодекс Німеччини).

${ }_{33}$ Див. справу RGSt, Urteil v. 19 Mai 1905 - ERG 38 [1906], 62, стор. 62-64.

${ }^{34}$ Societe Plon c. France, [2004] ECHR 200, параграф 19. 
Апеляційного суду м. Гренобль у справі Жирара (1900р.) в коментарі до справи $\left.{ }^{35}\right)$. Лурат згадує, що у більш стародавньому праві Франції професійна таємниця відносилася до священиків, одного з яких за розголошення таємниці сповіді чекала невтішна доля - він був повішений у 1672 році ${ }^{36}$. Жан Домат (1777 р.) у своїй книзі щодо публічного права Франції зазначає, що «корені» медичної таємниці лежать у римському праві [29, с. 129-130]. Систематизованої «донаполеонівської» чи бодай належно описаної практики судів, вочевидь, не існувало, а якщо вона існувала то, ймовірно, до наших часів вона просто не дожила, тому зробити якісь висновки стосовно того, якими принципами оперували суди, зараз майже неможливо.

Требуше був першим, хто окреслив проблемні питання в сфері медичної таємниці: 1) чи можна дозволити лікареві свідчити тоді, коли він, за результатами розтину, вбачає неприродну смерть ${ }^{37}$ (у прикладі в неназваному процесі 1830 року, який він наводить, - отруєння з летальними наслідками)? На його думку - це досить спірно; 2) Чи повинен доктор надавати всі персональні дані біологічних батьків до міського реєстру відповідно до ст. 56 ЦК Франції? Він відповів ствердно; 3) Чи повинен лікар повідомити про хворобу пацієнта, що не оплатив його роботу, позиваючись до нього в суд? Требуше вважає, що ні, однак позиватися слід за порушення умов договору між лікарем та пацієнтом; 4) Чи повинен лікар повідомити дружину (чи наречену) пацієнта щодо хвороби, наявної в нього? Требуше вважав, що так, та й апеляційний суд Ліона в рішенні по справі “ $G$ ” (1909 р.) був схожої думки, вважаючи, що розголошення медичної таємниці роботодавцеві до «виключень» не належить ${ }^{38}$. Апеляційний суд Гренобля у справі “ $M$ ” (1909 р.) дійшов висновку, що подання лікарем, уповноваженим для експертного висновку щодо нещасного випадку на виробництві (постраждалим в якому був позивач), такого висновку до суду, не є порушенням медичної таємниці ${ }^{39}$.

Практику французьких судів XIX та XX століть так само можна згрупувати за процесуальним та позапроцесуальним розголошенням медичної таємниці. Мабуть, найпершою з відомих справ стала Fournier c. Remusat, рішення по якій виніс Апеляційний суд Гренобля ще в 1828 році - вона може претендувати на звання найстарішої в цивільному процесі, де підіймається медична таємниця. Дружина Ремусат ініціювала позов. В якості свідків був покликаний лікар Фурньє, який мав свідчити стосовного того, що він лікував їі від хвороби (вочевидь венеричної), якою той їі заразив. Лікар, однак, відмовився свідчити, будучи свідком зі сторони позивача. Позивачка та її адвокати заявили, що лікар неправильно застосував свій «привілей не свідчити», адже ці свідчення були в її інтересах. Суд першої інстан-

${ }^{35}$ Procureur gen. de la Cour de Appel de Besancon c. Girard., Cour. de. cass, Cham. crim.; 10 May 1900; 15 Fevr. 1901, Dall. Per. 1905 I 553, стор. 553-554.

${ }^{36}$ Там же, стор. 554.

${ }^{37}$ Певним чином це питання охоплювалося у справі Шедана, одній з ранніх справ стосовно анонімності пологів, див. Chedanne, Cour d'Appel de Angers, 18 novembre 1850, Dall. Per. 1851 II 20.

${ }^{38}$ G c. R., Cour d'Appel de Lyon, 16 juin 1909, Dall. Per. 1910 II 123, 125.

${ }^{39} M$ c. Docteur V., Cour d'Appel de Grenoble, 29 janvier 1909, Dall. Per. 1910 II 121, 121-122. 
ції постановив лікареві свідчити, через що той подав апеляцію. Апеляційний суд Гренобля вирішив на користь лікаря, адже той так чи інакше зберігав «секрет» і не мав розголошувати його, навіть будучи свідком зі сторони позивачки ${ }^{40}-$ тоді суди трактували поняття медичної таємниці як «абсолютне» і не воліли самотужки випрацьовувати виключень (власне, ще Требуше згадував, що з нормативного змісту ст. 378 КК Франції було цілковито незрозуміло, які є межі «медичної таємниці» [1, с. 277-282]).

Декілька справ були пов'язані з інформацією про стан здоров'я пацієнта в контексті відшкодування позивачу або його родичам (у разі смерті) страхового полісу: тут не обійшлося без маніпуляцій, адже громадяни Франції, як свідчить практика, навчилися грамотно приховувати хвороби, оскільки статути страхових компаній Франції не дозволили би видавати таким громадянам поліс через те, що в них наявні деякі прогресуючі захворювання, що призводять до смерті ${ }^{41}$. У двох «справах-близнюках» із цивільного суду м. Гавр (1886 р.) та цивільного суду м. Бесансон (1887 р.) страхові компанії, аби не платити суму полісу за смерть застрахованого, намагалися отримати підтвердження в лікарів стосовно причин їх смерті. В обидвох справах суди визнали право лікаря відмовлятися видавати таке свідоцтво, якщо пацієнт (при житті) йому не дозволить це зробити. Хоч така позиція є досить анахронічною в сучасному світі, безперечно, така позиція як лікарських синдикатів (згадується у справі з м. Гавр), так і судів є цікавою ${ }^{42}$.

У справі КС Франції Bousquet c. Compaigne le Gresham (1899 р.) чоловік на прізвище Бускет у травні 1892 року купив страховий поліс із сумою страховки 70 тисяч франків від імені чоловіка на прізвище Фор (Faure). Фор невдовзі помер (у кінці 1892 року) через прогресуючий туберкульоз. В якості доказу Бускет надав епікриз, аби підтвердити вимогу виплатити всю суму полісу. Страхова компанія відмовилася, підозрюючи, що насправді Фор приховав хворобу сечового міхура і використовував фістулу для сечовипускання, а статути забороняли компанії страхувати таких громадян, як і скасування виплати полісу в разі неточностей у страховому договорі щодо стану здоров'я. В суд був покликаний доктор Ф., що раніше надав епікриз і лікував Фора протягом останніх 12 років його життя. Апеляційний суд Парижа дозволив використовувати свідчення лікаря Ф. в якості доказів. Тоді ж позивач подав касаційну скаргу. Касаційний суд визнав рішення суду недійсним, вважаючи свідчення лікаря недопустимими в якості доказів. У той же час, обов'язок лікаря свідчити ніяким чином не відміняється, і суд може задати йому питання, на деякі з яких він має право не відповідати. Щоправда, поняття того, яка інформація є «секретом», а яка не є, відповідно до нотатки справи - самі суди чітко не випрацювали, тому результат цього може мінятися від справи до справи залежно від обставин ${ }^{43}$.

${ }^{40}$ Fournier c. Remusat, Cour d'Appel de Grenoble, 23 aout 1828, Sirey 1828 I 318, 319-320.

${ }^{41}$ Bousquet c. Compaigne le Gresham, Cour de Cass., 1 Mai 1899, 1899 Dall. Per. I 585, 587.

${ }^{42}$ Traffault c. Boutan, Trib. civ. Du Havre, 30 juillet 1886, Sirey 1887 II 69, Dall. Per. 1887 I 347; Daguet c. Garderon et. Comp. d'assur sur la vie Phenix, Trib. civ. de Besancon, 17 fevrier 1887, 1887 Jour. du. Pal. 476, 477-478.

${ }^{43}$ Там же, стор. 587-588. 
Позапроцесуальні розголошення медичних таємниць наприкінці XIX століття найперше характеризувалися викладкою історії хвороб пацієнтів з інформацією про їх особу, що часом породжувало гучні судові позови. Одна з найгучніших та найвідоміших справ із розголошення медичних таємниць - справа Уателета та Дале (1885р.), в якій проти лікаря було відкрито кримінальне провадження за фактом розголошення інформації щодо перебігу хвороби і смерті відомого французького художника ЖЖюля Бастьєн-Лепажа (1848-1884 р.p.). Історію хвороби він передав до газети “La Matin” (П. Бруардель подає копію листа Уателета у своїй першій книзі [6, с. 19-21]).

Бастьєн-Лепаж, будучи хворим на рак, 10 років подорожував Алжиром і повернувся зі слабким станом здоров’я. В листі Уателет згадує, що художник також був хворий на ревматизм, і що він помер внаслідок ускладнень раку, а медицина була безсила його врятувати [6, с. 21-22]. Уателет був засуджений до штрафу у Корекційному суді м. Сени, програвши і апеляцію. Касаційний суд Франції зазначив, що відсутність злого умислу в його діях від відповідальності не звільняє і «завдає шкоду не тільки особі, а й усьому суспільству, адже тоді втрачається довіра до професій, яким суспільство довіряє...». Касаційний суд підтвердив рішення судів нижчих інстанцій у справі Уателета ${ }^{44}$.

Справа Уателета також згадується в рішенні Європейського суду з прав людини по справі Plon (Societe) v. France, яка стала основою для каскаду рішень Касаційного суду Франції ${ }^{45}$. До того ж, принципи, випрацювані в рішенні по справі Уателета, є цілком співставними з рішенням ЄСПЛ по цій справі, як і самі обставини справи. Пізніше, підсумовуючи справу Уателета (1885 р.) в рішенні по справі Консула (1893-1895 р.p.), Касаційний суд Франції зазначив, що публічність позивача (чи то померлої особи, родичі якої судяться за порушення медичної таємниці), не $\epsilon$ виправданням для розголошення медичної таємниці ${ }^{46}$.

На жаль, справу Консула Європейський суд з прав людини у своєму рішенні не згадав, при тому, що її обставини також багато в чому співставні зі справою Societe Plon 2004 року, а загальні правила, випрацювані в ній, цілком могли б лягти в основу багатьох рішень Європейського суду з прав людини. Багато в чому цьому посприяла не тільки справа Уателета (1885 р.), а і дві наступних: їхній лейтмотив можна буде охарактеризувати наступним чином: чи є науковий інтерес до ряду рідкісних хвороб індульгенцією до розголошення лікарем медичної таємниці? Суди Франції сформулювали свою позицію досить чітко.

У справі «B» директор психлікарні в м. Бесансон опублікував буклет, де він описав історію хвороби (позивачки, яка, за його спостереженнями, хворіла на мономанію, що спричинило два позови - від прокурора та самої позивачки. Він був оштрафований на 2200 франків (з яких лише 200 за розголошення медичної таємниці). Чоловік подав апеляцію задля зменшення суми відшкодування збитків.

${ }^{44}$ Watelet et Dallet c. Min. Publ., Cour de Cass., Cham. Crim, 19 decembre 1885, Dal. Per.1886 I 347, 347-348.

${ }^{45}$ Editions Plon (Societe) v. France, [2004] ECHR 200, (2006) 42 EHRR 36, параграф 20.

${ }^{46}$ Див. нотатку до справи Consul c. Pitres, Cour. de cass.; Cham. Civ., 9 avril 1895, Sirey 1896 I 81 (Автор - А. Тенон). 
В ході аналізу доказів, «Х» втекла з психлікарні і через кілька днів, коли її впіймали, то направили до закладу позивача. Дещо пізніше, за спостереженнями позивача («В»), був опублікований буклет, надрукований тиражем у 800 копій. Історія хвороби «Х» була детально описана, і про особу «Х» можна було здогадатися, оскільки позивач згадував їі чоловіка по імені. Позивач наголошував, що зробив публікацію в інтересах науки, проте суд сказав, що це не є причиною порушувати конфіденційність пацієнта (тут можна додати, що Апеляційний суд м. Бордо в справі Консула (1893 р. $)^{47}$ заявив, що сам по собі опублікований опис історії хвороби пацієнта, фотографії та процес його лікування порушенням медичної таємниці не є; однак лікарю не дозволяється ідентифікувати свого пацієнта, що вже буде порушенням). Також Апеляційний суд Бесансона зазначив, що більшість фактів із буклету в дійсності були переписані з ранніх записів, що також не давало підстав порушувати медичну таємницю ${ }^{48}$. Варті уваги й гучні «справи Консула», які затягнулися на три роки - ці процеси можна вважати «класикою» із захисту конфіденційності даних пацієнтів епохи кінця XIX століття.

Справа Консула (1893-1895 р.р.) є не менш цікавою не тільки обставинами та рішенням судів (Апеляційний суд м. Бордо та Касаційний суд Франції), а й тим, що суди випрацювали ряд правил, які могли б суттєво допомогти вирішувати подібні справи як ЄСПЛ, так і судам тих держав, де не існує достатньої кількості судових прецедентів стосовно розголошення медичної таємниці. Вартує уваги і вік цього рішення, а також передові ідеї французьких суддів кінця XIX століття: до прикладу, в тій же Англії, де фактично не існувало (i, в принципі, досі не існує) усталених загальних правил, випрацюваних на підставі прецедентного права, щодо допустимості розголошення інформації про стан здоров'я пацієнта (дивись окремо підрозділ стосовно Англіі). Отже, позивачка у справі Жозефіна Консул, тітка Пауліни Консул (нар. 1860-ті-пом. до 1891), подала позов проти відомого французького психіатра і невролога Альбера Пітра (1848-1928 р.р. $)^{49}$ за публікацію історії хвороби, фотографій та численних описів симптомів хвороб однієї зі своїх пацієнток, Пауліни, вже померлої на час подачі позову. Пауліна була пацієнткою госпіталю Сент-Ендр у Бордо, де лікувалася протягом чотирьох років. Весь цей час Пітр (відповідач) записував симптоми та процес її лікування. Хворобу він назвав «одностороннім гіпнозом» : молода жінка, будучи 20 -річною на момент прийому в стаціонар, хворіла протягом усього дитинства, кілька років провела в монастирі, де її здоров'я часом покращувалося. Після смерті їі матері (близько 1882 року) її здоров’я знову різко погіршилося. Переважно, вона страждала від цілої гамми психічних розладів. Свої спостереження Пітр виклав у двотомнику "Leçons cliniques sur l'hystérie et l'hypnotisme. Faites à l'Hôpital Saint-André de Bordeaux” (1891р. $)^{50}$, де племінницю позивачки позначив як “Pauline C.”, де також розмістив фотографії Пауліни. Пауліна

${ }^{47}$ Consul c. Pitres, Cour d'Appel de Bordeaux, 5 juillet 1893, Dall. Per. 1894 II 177, 177-178.

${ }^{48}$ B... c. X...., Cour d'Appel de Besancon, 22 mai 1888, Sirey 1888 II 128.

${ }^{49}$ Consul c. Pitres, Cour. de Cass., Cham. civ., 9 avril 1895, Sirey 1896 I 81, 82.

${ }^{50} \mathrm{~A}$. Pitres, Leçons cliniques sur l'hystérie et l'hypnotisme. Faites à l'Hôpital Saint-André de Bordeaux, Tome Second, Paris, (O. Doin, Editeur), 1891. Безпосередньо з книги узято деякі обставини хвороби племінниці позивачки, див. ст. 321-328; 479-480. 
померла перед публікацією книги, а позов подала її тітка. Апеляційний суд Бордо спершу зазначив, що медична література дійсно часто описує випадки з історії хвороб, детально виділяючи симптоми та процес лікування, що може включати ініціали пацієнта, фотографії цих симптомів та патологій? Чи є це порушенням медичної таємниці в такому разі? Нi, якщо пацієнта неможливо ідентифікувати за допомогою відомостей; однак, у той же час, лікар не має права надавати конкретних фактів щодо особи пацієнта - інакше це є порушенням (до схожих висновків дійшов і Апеляційний суд Парижа в справі Уателета (1885 р. $\left.)^{51}\right)$. Оскільки сама Пауліна померла, то право позиватися до суду належить її спадкоємцю або ж родичеві. Однак, правовою підставою для позову є не ст. 378 КК, а ст. 34 Закону від 29 липня 1881 року ${ }^{52}$ - себто, наклеп відносно померлого: відповідно, це вже цивільний позов. До того ж, позивач не виграє справу, якщо не доведе, що публікація завдала шкоду репутації нині живій особі чи може їі завдати в майбутньому ${ }^{53}$. Позивачка вважала, що фотографія була непрямою «персоніфікацією її сім’ї, однак суд це не розцінив, як завдану шкоду. До того ж, за встановленими фактами, суд зазначив, що Пауліна із задоволенням читала всі висновки Пітра та охоче згодилася на їх публікацію, включаючи і фотографії ${ }^{4}$. До того ж, Альбер Пітр запропонував позивачці вилучити фотографії Пауліни. Тому позивачці не вдалося довести вчиненої їй шкоди, і суд вирішив позов на користь відповідача. Касаційний суд підтвердив рішення нижчої інстанції55. Завдяки цій та низці інших справ суди Франції змогли вивести декілька загальних правил по вирішенню справ із розголошення медичної таємниці. Їх можна навести нижче:

1. В разі того, якщо наукова робота з медицини, в якій опублікована історія хвороби, складена з інформації, отриманої в ході виконання лікарем його роботи, і подані ним факти ідентифікують особу позивача - це порушення медичної таємниці ${ }^{56}$.

2. Фотографії, ініціали, згадка про родичів ${ }^{57}$ та історія хвороби можуть бути «ідентифікаторами» особи.

3. Науковий інтерес точно не $є$ індульгенцією для розголошення медичної таємниці. Такою є виняткова суспільна потреба, якою, згідно прийнятого у 1893 році закону у Франції 58 є обов' язок репортувати стосовно епідемій [8, с. 16-33] (власне, такевиключення дужешвидко з' явилося і в праві СШАще напочатку ХХ століття ${ }^{59}$ ).

${ }^{51}$ Watelet et Dallet, gerant du journal Le Matin, Cour d'Appel de Paris, 5 mai. 1885, Sirey 1885 II 121, 121-122 (автор нотатки до справи - Віллей).

${ }^{52}$ Loi du 29 juillet 1881 sur la liberté de la presse, Art. 34.

${ }^{53}$ Pitres c. Demoiselle Josephine Consul., 5 juill. 1893, Cour d'Appel de Bordeaux, Dall. Per. 1894 II 177, 177-178.

${ }^{54}$ Цей факт наводить Касаційний суд у своєму рішенні, див. Consul c. Pitres, 9 avril 1895, Cour. de cass., Sirey 1896 I 81, 84.

${ }_{55}^{5}$ Taм же, Consul c. Pitres, 9 avril 1895, Cour. de cass., Sirey 1896 I 81, 84.

${ }^{56}$ Pitres c. Demoiselle Josephine Consul., 5 juill. 1893, Cour d'Appel de Bordeaux, Dall. Per. 1894 II 177, 178.

${ }^{57}$ B... c. X..., Cour d'Appel de Besancon, 22 mai 1888, Sirey 1888 II 128.

${ }^{58}$ Dall. Per. 1893 IV 14.

${ }^{59}$ Simonsen v. Swenson, 104 Neb. 224, 228-230; 177 North-Western Reptr. 831, 832 (1920). 
4. Якщо особа, дані якої розголошені, померла, то правовою підставою для позову є ст. 34 закону від 29 липня 1881. Якщо жива - ст. 378 КК. Позивач має довести на суді, що публікація завдала саме йому (а не померлому) моральну шкоду (справа Консула). Засобом правового захисту є: позов щодо відшкодування збитків; позов щодо заборони публікації матеріалів (рішення Касаційного суду по справі Консула ${ }^{60}$ ).

5. Відсутність злого умислу не є виправданням для розголошення (справи Уателета та Консула $)^{61}$.

6. В деяких випадках пацієнт може дати згоду на розголошення таємниці, але його родичі - за умови того, що він помер - ні ${ }^{62}$.

7. Лікар насправді не звільняється від обов’язку свідчити щодо всього, що він побачив і почув у повсякденному житті ${ }^{63}$.

8. Досить важко однозначно сказати, чи дійсно всі факти, отримані лікарем, $є$ конфіденційними за характером. Іноді їх характер оцінювався суддями безпосередньо на процесі, тому «вгадати», що буде ним вважатись, а що ні, непросто ${ }^{64}$.

9. У французькому праві початку XX століття, суди спробували визначити, що можна вважати «секретним фактом», і дійшли висновку, що пацієнт має мати певний інтерес для того, аби приховувати якусь інформацію, яку він делегує лікареві ${ }^{65}$.

10. Професійна - в цьому випадку медична таємниця у праві Франції рівна власності і належить тому, хто довірив її лікареві - він і є розпорядником таємниці та може дати лікареві право розголосити її в разі потреби ${ }^{66}$.

11. Свідчення, які надав доктор (не виключено, що під примусом), судами не допускаються в якості доказів, якщо суд вважатиме, що докази отримані в обхід медичної таємниці ${ }^{67}$.

12. На суді позивач має право вносити медичну документацію, підготовану його лікарем в якості доказів ${ }^{68}$.

13. Якщо підприємство, на якому працевлаштований позивач, уповноважує лікаря зробити експертний висновок щодо втрати його працездатності, то надання підприємству цього висновку порушенням медичної таємниці не $\epsilon^{69}$. Щоправда, якщо лікар не є спеціально уповноваженим для цього, то тоді він порушує медичну таємницю, надавши роботодавцям інформацію про стан здоров'я позивача ${ }^{70}$.

\footnotetext{
${ }^{60}$ Consul c. Pitres, Cour. de Cass., Cham. civ., 9 avril 1895, Sirey 1896 I 81.

${ }^{61}$ Див. нотатку до справи Pitres c. Demoiselle Josephine Consul., 5 juill. 1893, Cour d'Appel de Bordeaux, Dall. Per. 1894 II 177.

${ }^{62}$ Trafault c. Boutan, Trib. civ. du Havre, 30 juillet 1886, Sirey 1887 II 69.

${ }^{63}$ Bousquet c. Compaigne le Gresham, 1 Mai 1899, Cour de Cass., 1899 Dall. Per. I 585, $585-587$.

${ }^{64}$ Bousquet c. Compaigne le Gresham, Cour de Cass., 1 Mai 1899, 1899 Dall. Per. I 585, 587-588; Erlander c. Soc. Venot et Co., Cour de Cass., 26 mai 1914, Sirey 1918 I 9, 9-11.

${ }^{65}$ Bousquet c. Compaigne le Gresham, 1 Mai 1899, Cour de Cass., 1899 Dall. Per. I 585, 585-587; Erlander c. Soc. Venot et Co., Cour de Cass., 26 mai 1914, Sirey 1918 I 9, 10.

${ }^{66}$ Proc gen. de la Cour d'Appel de Besancon c. Girard., Cour. de. cass, Cham. crim.; 10 May 1900; 15 Fevr. 1901, Dall. Per. 1905 I 553, 553-554.

${ }^{67}$ Bousquet c. Compaigne le Gresham, 1 Mai 1899, Cour de Cass., 1899 Dall. Per. I 585.

${ }^{68}$ Erlander c. Soc. Venot et Co., Cour de Cass., 26 mai 1914, Sirey 1918 I 9, 9-10.

${ }^{69} M$ c. DocteurV., Cour d'Appel de Grenoble, 29 janvier 1909, Dall. Per. 1910 II 121, 121-122.

${ }^{70} G$ c. R., Cour d’Appel de Lyon, 16 juin 1909, Dall. Per. 1910 II 123, 125.
} 
У Бельгії розголошення медичної таємниці, як і у Франції, було злочином невеликої тяжкості, однак судова практика з цього питання нараховувала лічені справи, про що йшлося і в висновках бельгійських юристів XIX століття. 3 їх розуміння $^{71}$, «медична таємниця» не носила абсолютного характеру, тому лікарі давали свідчення щодо стану здоров'я своїх пацієнтів у суді. У одній зі справ Апеляційного суду м. Брюсель лікар Сутін, який був присутній на дуелі барона д’Оогворста та Альбера Гобле д’Альвьєли, в той час відомим бельгійським політиком, був покликаний в якості свідка. Суд поставив лікарю 5 питань, однак Сутін відмовився надавати свідчення щодо стану здоров'я пораненого, посилаючись на медичну таємницю, тому провадження відкрили і проти нього самого. Оскільки на той час дуелі були поза законом, то суд сказав, що Сутін не має права приховувати таку інформацію, оскільки вона прямо стосувалася скоєння злочину (дуелі) і відхилив апеляцію $^{72}$. Аналогічно, Касаційний суд Бельгії в справі Бесселса (див. нижче) постановив, що зловживання медичною таємницею задля того, аби приховати шахрайство, є категорично недопустимим ${ }^{73}$.

За аналогічним принципом у справі “L” та "S" (Апеляційний суд м. Гент, 1855 р.), де лікар і нотаріус через посередників викрали дитину, особу матері якої вони «анонімізували», а через деякий час віддали на виховання третім особам, Гентський апеляційний суд постановив наступне: зловживання медичною таємницею обвинувачуваними є недопустимим у їхній спробі приховати злочин (викрадення дитини $)^{74}$. Бельгійське право категорично не визнавало право лікаря чи іншого медперсоналу (наприклад, акушера) не надавати персональні дані біологічної матері у свідоцтві про народження на підставі медичної таємниці ${ }^{75}$. Справу Сутіна обтічно згадував Касаційний суд Франції у справі Жирара (1900р.), наголошуючи, що лікар, який допомагає на дуелі, точно не «зайнятий виконанням свого мистецтва» (в розрізі допустимості свідчень лікарів) ${ }^{76}$. Що цікаво, у Франції, у тому ж таки 1845 р., Касаційний суд виніс рішення по справі-«близнюку» бельгійської «справи дуелянта», а саме, справі Сен-Пера з дуже схожими обставинами та ідентичним рішенням суду ${ }^{77}$. Досить гарний огляд французької «справи дуелянта» здійснив адвокат Муте у книзі з теорії і практики захисту професійних таємниць (1870 р.) [2, с. 18-23].

Німеччина. Досить показовою є справа Штрафсенату Рейхсгеріхту (1905 р.) стосовно необхідності розголошення медичної таємниці. Одного разу лікар (відповідач) відвідав родину позивача, визначивши, що жінка хвора на сифіліс. Ба-

${ }^{71}$ Див, Hubert, Secret medical, Journal de Tribunaux (Bruxelles), 1897.369, 371-373.

${ }^{72}$ Min. Publ.c. Seutin, Cour d'Appel de Bruxelles, 25 mai. 1845, Pas. 1845 II 307, 307-308.

${ }^{73}$ Min. Publ c. L.. et S.., Trib. Corr. De Gand, 28 juin 1856, B.J.1856.998, 999-1002; $1005-1008$.

${ }^{74}$ Min. Publ c. L.. et S.., Trib. Corr. De Gand, 28 juin 1856, B.J. 1856.998, 999-1002; $1005-1008$.

${ }^{75}$ Bessems c. Le Ministere Public, Cass. 20 juillet 1855, Pas. 1855 I 303, 305-307; 308-309.

${ }^{76}$ Proc gen. de la Cour d'Appel de Besancon c. Girard., Cour. de. cass, Cham. crim.; 10 May 1900; 15 Fevr. 1901, Dall. Per. 1905 I 553, 554.

${ }^{77}$ Saint Pair c. Min. Publ., 26 juil. 1845; Cour de Cass. Jour. du. pal. 1845 I 289. 
чачи, що діти постійно контактують із матір'ю, лікар вирішив попередити про небезпеку невістку позивачки, яка проживала спільно з нею. Оскільки доктор розголосив діагноз, позивачка подала позов проти нього: міський суд Берліна постановив оштрафувати відповідача на 20 рейхсмарок. Штрафсенат Рейхсгеріхту в апеляції відповідача прийняв його сторону: хоча суд не заперечував, що відповідач розголосив лікарську таємницю, однак питання його відповідальності за це лежало в площині обгрунтування таких дій. Конкретно в цьому випадку, на думку Рейхсгеріхту, лікар не те, що міг, а повинен був розголосити медичну таємницю: в протилежному випадку, якби діти заразились сифілісом, він міг би понести відповідальність за професійну недбалість ${ }^{78}$. Що цікаво, позиція суду стосовно допустимості розголошення медичної таємниці на процесі була протилежною: у позові щодо розлучення лікар був покликаний підтвердити, що чоловік позивачки був заражений сифілісом (як передбачалося, внаслідок зрад), однак доктор відмовився підтвердити діагноз навіть попри те, що суд скерував відповідача «зняти мовчання» ${ }^{79}$ з нього. Цівільсенат Рейхсгеріхту, втім, дійшов висновку, що зобов'язання лікаря зберігати медичну таємницю є, в деякому розумінні, «вищими», ніж інтерес позивача розірвати шлюб, а отже, дозволив лікареві не свідчити щодо діагнозу відповідача ${ }^{80}$.

У праві Німеччини ХХ століття інтерпретація судами розголошення медичної таємниці, як і в багатьох інших країнах Європи, лежить у двох площинах: 1) допустимість розголошення медичної таємниці на цивільному чи кримінальному процесі; 2) позапроцесуальне розголошення. Не варто забувати, що дані про стан здоров'я можуть виявитися доказами на процесі (наприклад, лікарської халатності), тому в таких випадках суди вважали, що ненадання доступу до лікарняної картки пацієнта не можна виправдати медичною таємницею ${ }^{81}$. В Німеччині, як у Франції та США, медична таємниця охоплюється як справами щодо розголошення будьяких даних про стан здоров'я пацієнта будь-якій третій особі, включаючи персонал лікарні, який не є лікарями ${ }^{82}$, так і правом лікарів ${ }^{83}$ та медсестер ${ }^{84}$ не надавати свідчень на цивільному і кримінальному процесі (щоправда, нерідко німецькі суди доходили висновку, що в разі того, якщо покази є необхідними, то лікарям все ж доводилося свідчити ${ }^{85}$.

${ }^{78} R G$, Beschluss v. 19 Mai 1905 - ERG II (Strafsenat) Bd. 38 [1906], 62, стор. $62-66$.

${ }^{79}$ В праві Німеччини, аби лікар мав право давати свідчення стосовно стану здоров'я позивача, сам позивач має надати дозвіл на це в суді, див. справу ... В разі того, якщо покази стосуються стану здоров'я відповідача, то тоді суд скеровує його надати цей дозвіл, як, власне і сталося у справі Рейхсгеріхту 1903 р. (див. справу. Траплялися випадки, коли дозвіл лікареві давати свідчення щодо свого стану здоров'я давав і відповідач.

${ }^{80} \mathrm{RG}$, Beschluss v. 19 Januar 1903 - ERG VI (Zivilsenat) Bd. 53 [1903], 315, стор. 315-319.

${ }^{81}$ Див. справу Верховного Суду Німеччини, BGH, 31.05.1983 - VI ZR 259/81, параграф. $2-6,19-20 ; 25 ; 28 ; 30$.

${ }^{82}$ LAG Niedersachsen, 15.09.1993; 5 Sa. 1772/92 (параграфи різні).

${ }^{83} B V e r W G, 25.09 .1958$ - BVerWG WDB 9/58 (різні).

${ }^{84} B G H, 20.02 .1985$ - 2 StR 561/84, особлива увага на параграфи 7-11 та 1-14 рішення суду.

${ }^{85}$ BVerWG, 25.09.1958 - BVerWG WDB 9/58. 
У справі Ландсгеріхту м. Кельн (1959 р.), працівник реєстратури отримав штраф, відмовившись надати список пацієнтів гінекології клініки. ЖЖінку, клієнта клініки, обікрали в ній. Постраждала просила надати список пацієнтів, аби вияснити, хто це міг зробити. Рецепціоніст на суді відмовився надавати покази, зіславшись на медичну таємницю. Суд зазначив, що список пацієнтів покривається поняттям «медична таємниця» для професійного застосування, однак не у випадку того, якщо ця інформація може стати доказом скоєння злочину, і підтвердив рішення суду нижчої інстанції ${ }^{86}$.

У справі Федерального суду Німеччини 1985 р. медсестра була оштрафована через відмову дати свідчення щодо осіб зловмисників, одного з яких поранили під час невдалого пограбування магазину електротехніки: суд вирішив, що вона не має права приховувати факти, окрім тих, що стосується лікування злочинця, як пацієнта ${ }^{87}$. У більш пізній справі Регіональний суд із трудових спорів Нижньої Саксонії визнав порушенням медичної таємниці розголошення даних про стан здоров'я позивача, що був пацієнтом персоналу лікарні, який не був лікарем, постановивиши відшкодувати йому 6000 дойчмарок ${ }^{88}$.

\section{Англо-саксонське право}

Сполучені Штати Америки. Класифікація поділу розголошення «медичної таємниці» на процесуальну (judicial) та позапроцесуальну (extrajudicial) цілком прижилася у адвокатській літературі США та Канади в 1950-х, про що свідчать роботи Фрідмана (1954р.) та ДеВітта (1954р.), які одними з перших запропонували їх класифікувати цим методом [11, с. 19-23] [12, с. 7-11], а в 1960-х роках Ч. Рьодерсхаймер розглядав питання деліктної відповідальності за розголошення лікарем медичної таємниці на основі практики американських судів 1930-1960-х (тут можна додати, що Апеляційний суд штату Орегон у справі Humphers v. First Intestate Bank (1984 р.) стосовно розголошення даних про особу біологічної матері всиновленій дочці, описаній у цій статті, також аргументовано підійшов до питання деліктної відновідальності саме у цій площині ${ }^{89}$ ).

Практика судів США XIX століття щоправда не розрізняла такого поняття, як "extrajudicial disclosure", швидше за все через відсутність ${ }^{90}$ таких справ [4, с. 148-151], зводячи існуючу практику судів до питання допустимості використання свідчень лікаря в якості доказів на цивільному та кримінальному процесі. У XIX випуску Енциклопедії Британського та Американського Права (1892 р.) не згадуються жодні справи стосовно позапроцесуального розголошення медичної та-

${ }^{86}$ LG Koln 02.04.1959 - 34 Qs 76/59; NJW 1959, 1598, стор. 1598-99.

${ }^{87}$ BGH, 20.02.1985 - 2 StR 561/84, параграф 7-11; 13-14.

${ }^{88}$ LAG Niedersachsen, 15.09.1993; 5 Sa. 1772/92 (різні).

${ }^{89}$ Апеляція по справі Humphers v. First Intestate Bank, 68 Or. App. 573, 578-587 (1984), підтвердження рішення по справі Верховним Судом шт. Орегон, США, Humphers v. First Intestate Bank, 298 Or. 706 (Or. 1985), окремо див. сторінки 719-722 (щодо деліктної відповідальності за порушення довіри (breach of confidence).

${ }^{90} 3$ цим, однак, можна не погодитись певною мірою за наявністю такого артефакту, як справи DeMay v. Roberts, 46 Mich. 160 (1881), хоча доволі курйозні обставини загалом не заторкали питання розголошення інформації про пацієнта: лікар (ДеМей), будучи втомленим, узяв собою друга (А. Скаттергуда) допомогти йому прийняти пологи. Чоловік цієї жін- 
ємниці, у той же час питання допустимості свідчень лікаря підіймалося у різних штатах у практиці XIX століття. Раннє прецедентне право США не встановлювало такого поняття як “patient-physician privilege" (або обов' язку, хоч і не абсолютногоце нерідко вирішували суди, що покладався на лікаря, не свідчити стосовно стану здоров'я пацієнта). В той же час, у деяких штатах США приймалися спеціальні статути на кшталт норм Цивільного кодексу, які забороняли лікарям свідчити щодо стану здоров'я своїх пацієнтів: конфігурація цих статутів могла відрізнятися, бо в одних штатах лікарям заборонялося свідчити лише в цивільних справах, в інших - у кримінальних, а в деяких штатах такого «привілею» взагалі не існувало. Так, лише в 1883-1887 роках статутів було прийнято близько 20 [4, с. 147-150].

У Цивільному процесі (вказане твердження стосується тих штатів Америки, де лікарям не дозволялося свідчити щодо стану здоров'я пацієнта), вилучалися з процесу і не допускалися як «некомпететні» (англ. «incompetent testimony») свідчення лікарів, які містили інформацію, отриману ними в ході спілкування з пацієнтами, наприклад, у справах щодо відшкодування суми полісу за смерть застрахованого ${ }^{91}$, щодо стану здоров'я одного з подружжя (як доказ існування зради у випадку зараження венеричним захворюванням) $)^{92}$. Правова природа "patient-physician privilege” відповідно до практики судів є змішаною, адже в одних штатах походить від статуту, в інших - від прецеденту (і неодноразово - «позиченому» з практики судів інших штатів ${ }^{93}$ ). Досить рано в судовій практиці США були визначені «наріжні камені» медичної таємниці, кого можна вважати «депозитарієм таємниці», i в якому випадку лікар є тим, хто бере опіку над пацієнтом; і який спосіб видобування інформації, що становить цю медичну таємницю [4, с. 148].

ки (Робертс), якому ДеМей сказав, що привів з собою товариша, без вагань погодився його впустити, не знаючи, що той не є лікарем. Під час пологів, друг ДеМея активно йому допомагав, і одного разу вхопив жінку за руку. Втім, немовля народилося здоровим, і обійшлося без жертв. Однак, Робертс подала в суд на ДеМея та його друга Скаттергуда за обман та «побої» (еквівалент делікту «battery»). Суд вирішив на користь Робертс. В іншій справі, Bazemore v. Savannah Hospital, 171 Ga. 257, 258-259, 262-263 (1930), у позивачів народилася дитина з ектопією серця (ectopia cordis). Їх дитина померла невдовзі після народження, і персонал лікарні дозволив журналістам місцевого видання сфотографувати тіло дитини. Верховний Суд штату Джорджія вирішив на користь позивачів. Обгрунтування правової позиції було напрочуд цікавим, адже окрім справ щодо порушення «права на приватність» (right to privacy), Суд згадував і справи, які загалом, можна охарактеризувати як позови щодо відшкодування моральної шкоди («mental anguish»), або аутрейдж («outrage»). Так, найбільш гротескною справою, згаданою судом, була Jacobus v. Congregation of the Children of Israel, $107 \mathrm{Ga} .518,519-520,522-524$ (1899). В ній, позивач судився з директором цвинтарю, який зайшов з помічниками на його територію, знищив могильні камені, дістав труни та ... безцеремонно викинув рештки його родичів з трун прямо на очах у багатьох людей, згодом перепоховавши рештки у «невідомому місці на цвинтарі». Причина його поведінки не була наведена. Хоча справа була маркована у витягу, просто як "action for damages" (позов для відшкодування збитків), справи з шокуючою, безсоромною поведінкою відповідача, сформували новий делікт - "outrage".

${ }^{91} 3$ практики судів США ХIX століття, див. Edington v. Mutual Life Insurance Company of New York, 5 M. T. Hun (New York) 1, 7-9 (1875); The Masonic Mutual Benefit Association v. Beck, 73 Ind. 203, 209-211 (1881).

${ }^{92}$ Cramer v. Hurt, 154 Mo. 112 (1900).

${ }^{93}$ The Masonic Mutual Benefit Association v. Beck, 73 Ind. 203, 209-211 (1881). 
Не вважалася недопустимою для розголошення на суді інформація, яку лікар (свідок) отримав в ході спілкування з хворим, який йому знайомий як товариш, або в інших випадках, коли пацієнт не перебував під його опікою ${ }^{94}$; таким, власне, вважався лікар, який відвідував пацієнта, і його асистенти ${ }^{95}$. Також нормальним явищем у практиці судів США було зняття медичної таємниці у випадку того, якщо пацієнт є позивачем і бажає, аби лікар був свідком з його сторони, особливо, якщо це позов щодо медичної халатності ${ }^{96}$.

Щодо способу видобування інформації, яка становить медичну таємницю, то ще в 1875 р. Верховний Суд штату Нью-Йорк зазначив, що вона складається як з тієї, що лікар отримав від пацієнта, так і з іншої, яку той отримав невербально в ході діагностики ${ }^{97}$. Через століття американські суди надавали досить подібне, вдосконалене визначення: ця інформація становить документовану в записах із медичних карт, отриману в ході розмови з пацієнтом і у процесі діагностики ${ }^{98}$.

Якщо статути і певною мірою практика судів США забезпечували збереження медичної таємниці на процесі, їх дія жодним чинол не стосувалась позапроцесуальних розголошень [X, с. 492-494], тому деліктна відповідальність з середини $\mathrm{XX}$ століття (якщо суд визнавав деліктом це розголошення) базувалася на таких деліктних теоріях: аутрейдж (англ. outrage), простіше кажучи, відшкодування збитків за нанесену моральну шкоду, якщо дії відповідача є відверто аморальними або шокуючими для суспільства), порушення умов договору між лікарем і пацієнтом (або, хоча б, «імпліцитного» договору ${ }^{99}$, або такі, що, на думку судів, хоч i не «прописні», однак є похідними від нього ${ }^{100}$ ), порушенням конфіденційності ${ }^{101}$ (власне, цей делікт не раз був визнаний судами найбільш адекватною деліктною теорією для таких позовів ${ }^{102}$ ). Іноді правовою підставою для такого позову могли стати і статути ${ }^{103}$.

Цікаво, в ранніх позовах можна було побачити і інші деліктні теорії, такі як наклеп: американські суди не надавали особливого значення конкретній деліктній теорії, зазначаючи, що позивач має право на відшкодування збитків за розголошен-

\footnotetext{
${ }^{94}$ Edington v. Mutual Life Insurance Company of New York, 5 M. T. Hun (New-York) 1, 4-5, 8-9 (1875). (1886).

${ }^{95}$ H. Streeter v. City of Breckenridge, 23 Mo. App. [Kansas City Ct. App.] 244, 251-253

${ }^{96} 3$ практики 19 століття див. справу Cooley v. Foltz, 85 Mich. 47, 48-49 (1891), з більш сучасних справ, див. Cates v. Wilson, 321 N.C. 1, 14; 361 S.E.2d 734, 741-742 (1987).

${ }^{97}$ Edington v. Mutual Life Insurance Company of New York, 5 M. T. Hun (New York) 1, 4-5, 8-9 (1875).

98 Див. справи: Capps v. Lynch, 116 S.E. 137, 140 (1960); Cates v. Wilson, 321 N.C. 1, 1314; 361 S.E.2d 734, 740-742 (1987).

${ }^{99}$ Див. Quarles v. Sutherland, 215 Tenn. 651, 658; 389 South-Western Rptr. 2d 649, 652 (1962); Alsip v. Johnson City Medical Center, 197 S.W.3d 722, 726-729 (Tenn. 2006).

${ }_{100}$ Див. наприклад, Hague v. Williams, 181 Atlantic Rptr. 2d 345; 37 N.J. 328, 336 (1962).

${ }_{101}$ Shea v. McCarden, 46 Pa, D \& C. 2d 560, 563 (1969); Doe v. Roe, 93 Misc. 2d. 201, 209 211 (1977); Humphers v. First Intestate Bank, 298 Or. 706, 719-722 (1985).

${ }^{102}$ Humphers v. First Intestate Bank, 298 Or. 706, 719-722 (1985).

${ }^{103}$ Див. коментар суду у справі Doe. Roe, 93 Misc. 2d. 201, 213 (1977), і як один з таких прикладів, Munzer v. Blaisdell, 183 Misc. 773 (N.Y. Misc. 1944).
} 
ня даних про його стан здоров'я ${ }^{104}$. Не менш курйозним $є$ і той факт, що в судовій практиці США середини ХХ століття траплялися справи, коли суди не розрізняли процесуальні та позапроцесуальні розголошення медичних таємниць ${ }^{105}$.

ДеВітт, досліджуючи практику судів США, зазначив, що до справи Сімонсена (про неї трохи нижче), знайти справу щодо позапроцесуального розголошення медичної таємниці не видавалося за можливе - це ж саме стосувалося і права Великої Британії (єдине «виключення з правил» - поодинока справа Whyte v. Smith з Шотландії, яку автор коротко опише у цій статті, як черговий «артефакт», яких вже було згадано в ній чимало) [11, с. 20] [19, с. 74-75] [28, с. 198].

3 початку XX століття практика судів США стала випрацьовувати ряд виключень із нерозголошення медичної таємниці. В одній із робіт автора ці виключення в практиці судів США були добре систематизовані [28, с. 197-198], тому автор коротко перелічує їх. Ще на початку XX століття законодавчі органи кількох штатів США (показовим, на думку Р. Болдвіна (1962 р. ) [15, с. 182-183] та автора статті (2019р.) [28, с. 199], є Небраска), приймали статути, згідно з якими лікар був зобов'язаний повідомляти дані про особу, хвору на небезпечне захворювання. Власне, тому позивач у справі Сілонсена, який після виявлення в нього сифілісу лікарем, був випроваджений із готелю, в якому він поселився, не зміг виграти у нього позов, оскільки той виконував приписи закону ${ }^{106}$. Ці ж приписи (знову ж, на прикладі практики судів штату Небраска) вимагали від лікарів повідомляти і стосовно венеричних захворювань ${ }^{107}$.

В подальшому, такі виключення стали охоплювати необхідність повідомляти стосовно захворювань раком та деяких інших небезпечних інфекційними захворюваннь, наскрізних та кульових поранень пацієнта, абортів, опіків, насилля над дітьми, а також деяких категорій злочинів ${ }^{108}$; суспільно-небезпечних осіб ${ }^{109}$, адреси проживання і імена батьків мертвих зародків (штат Нью-Йорк) $)^{110}$. У деяких позовах, як позови щодо медичної халатності, суди дозволяли використовувати картки пацієнтів в якості доказів за умови того, що така інформація буде використана лише для цього позову ${ }^{111}$. Таким чином, практика судів США свідчить про те, що виключень з «абсолютності» медичної таємниці більше, ніж достатньо.

Англія. Чимало дослідників зверталися до проблеми медичної таємниці в Англії та її історії, зокрема, К. ДеВітт (1953 і 1959 р.p.), О. Гоппер (1973 р.), А. Сем’юелс

${ }^{104}$ Smith v. Driscoll, 94 Wash. 441, 442 (1917). Також у справі Berry v. Moench (шт. Юта, $1959 \mathrm{p}$.$) , де лікар, надіслав психофізичну характеристику позивача батькам його нареченої,$ позивач судився за наклеп, проте суд вирішив передати цю справу до суду нижчої інстанції (Berry v. Moench, 8 Utah 2d 191, 201 (Utah 1958).

${ }^{105}$ Див. коментар суду в справі Horne v. Patton, 291 Ala. 701, 708 (1974).

${ }^{106}$ Simonsen v. Swenson, 104 Neb. 224, 226-228; 228-230.

${ }^{107}$ M. Brown v. E. T. Manning et al., 103 Neb. 540, 452 (1919), № 20962.

${ }^{108}$ Rea v. Pardo, 522 N.Y.S.2d 393, 396; 132 N.Y. App. Div. 2d 442, 445-446 (1987).

${ }^{109}$ Tarasoff $v$. Regents of the University of California, 17 Cal. 3d 425, 431, 444-445, 452 (1976); Davis v. Lhim, 124 Mich. App. 291, 298-302 (1983).

${ }^{110}$ State v. Jacobus, 348 N.Y.S.2d 907, 912-913ж 75 Misc.2d 840, 843-844 (1973).

${ }^{111}$ Garner v. Ford Motor Co., 61 F.R.D. 22, 23-24 (1973); Anker v. Brodnitz, 98 Misc. 2d 148, $151(1979)$. 
(1980 р.) та Д. Шуман (1985 р.) [11, с. $19-23]$. [13, с. $489-492]$ ], [19, с. $74-76]$, [20, с. 58-59], [21, с. 671-676]. Кожен із цих дослідників намагався зрозуміти причину як фактичної відсутності системизованої практики судів, так і вкрай малої кількості справ. Англія цілком може посперечатися з Францією по давності справ: так, у книзі Ф.Е. Біркенхеда (1926) згадуються справи кінця 17 століття, де свідчили лікарі (справа Коупера) [30, с. 91, 95-101], а Гайс і Бунн (1981 р.) та Д. Шуман $(1985$ р.) згадують гротескну «справу Каллендера», в якій жінок судили за відьмацтво, і лікарі давали покази, підтверджуючи надприродні сили обвинувачуваних [21, с. 672]. [31, с. 2] Вона датується 1662 p.

К. ДеВітт у своїй другій роботі (1959 р.) зазначає, що в Англії до середини XVI століття свідчити в судах було необов'язково, а отже, в ті часи питання так і не стояло [11, с. 488-489]. За даними американського адвоката Блуетта Лі (1921), згадки про паранормальні явища і здібності людей в практиці судів існували доволі часто, однак ніяких спеціальних правил стосовно доведення їх реальності, просто окрім як надання дійсних доказів, ніколи не існувало [21, с. 635-638]. Однією з перших (хоча, за тими ж свідченнями Шумана (1985) - далеко не перших) справ була справа «проти Графині Кінгстон», в якій суддя Менсфілд заявив, що видавати секрет пацієнта «було б величезним безчестям», однак свідчити на суді цілковито інша справа ${ }^{112}$.

Переходячи від «міфології» до цивільного процесу, можна згадати чи не найбільш відому у британському праві справу Whyte v. Smith (1851р.), якій К. ДеВітт (1953 р.) [11, с. 20-21], В. Бернфельд (1972 р.) [18, с. 12 16], О. Хоппер (1973 р.) $[19$, с. 74$]$ приділяють значну увагу. Дружина позивача (Уайта), старости церкви ( «Kirk»), у жовтні 1849 р. народила дитину: з часу одруження пари пройшло 6 місяців. Уайт попросив лікаря (Сміта) переконатися в тому, чи не народилася ця дитина недоношеною. Лікар Сміт підтвердив, що дитина доношена, про що він написав у своєму висновку; цей висновок він відправив і настоятелю церкви, який звільнив Уайта $з$ посади. Той одразу подав в суд на лікаря, який на суді стверджував, що у відносинах лікаря і пацієнта ніякої конфіденційності не існує, і ця «таємниця» не випливає з імпліцитного договору між ними (позов базувався на підставах деліктів "breach of contract" та "breach of confidence").

Сесійний Суд Шотландії відхилив його доводи, зазначивши, що конфіденційність відносин між лікарем та його пацієнтом не підлягає сумніву, і що імпліцитний обов'язок лікаря тримати таку інформацію в секреті цілком існуе, та визнається правом (з окремої думки Лорда Айворі), вирішивши на користь позивача ${ }^{113}$. Цікаво, що британське право довгий час «не знало» подібних справ після цієї. Проте, існували справи щодо допустимості свідчень лікарів на процесі, деякі з яких згадані в 17 випуску Британсько-Американської Енциклопедії Права (1892 p.) [4, c. 147].

${ }^{112}$ R.v. Duchess of Kingston, 20 How. St. Tr. [Howard's State Trials] 355, 572-73 (1776).

${ }^{113}$ Whyte v. Smith, Dec. 13, 1851; 14 D. 177, 179-180 (№ 46); 24 S. C. 78, 79-80 (1851) [D = Dunlop Reports; S.C. = Court of Sessions]. Що цікаво, репортажі витягу рішення суду відрізняються. У репортажі Алегзендра Данлопа наводиться більше обставин справи. 
У справі Гарнера (1920р.), яка була позовом щодо розлучення, в якій жінка підозрювала, що чоловік заразив її сифілісом, лікар був покликаний свідчити. Хоча спочатку він відмовлявся давати покази на підставі того, що урядова програма боротьби з сифілісом вимагала від нього, як працівника лікарні, виняткової секретності. Суддя оцінив чесність лікаря, однак, на його думку, вершення правосуддя є вищим за етику, тому лікар дав свідчення, підтвердивши, що чоловік позивачки дійсно хворів на сифіліс ${ }^{114}$. Д. Шуман (1985 р.) наводить кілька подібних справ у 1940-1950x роках [21, с. 676].

Медична таємниця також імпліцитно згадувалася у кількох справах щодо доступу до даних про стан здоров'я в рамках позову щодо медичної халатності. Так, у згаданій вище справі “D (Infants)” (1970р.), суд зазначив, що на вимогу закону щодо всиновлення (Adoption Act 1958, чинний 1958-1976), інформація щодо всиновлених неповнолітніх є конфіденційною, і працівники органів опіки, що нею володіють, окрім, як у суді, не мають право її розголошувати ${ }^{115}$.

В ряді справ з Англії щодо доступу до даних про стан здоров'я - до прийняття закону Administration of Justice Act 1970 p., документи з лікарень можна було витребувати лише за допомогою повістки ${ }^{116}$ - суди не дозволяли позивачеві мати доступ до своєї медичної історії, лише надаючи доступ медичним консультантам i, іноді, адвокатам ${ }^{117}$. Лікарі у Англії також повинні надавати інформацію щодо пацієнтів в разі запиту правоохоронних органів ${ }^{118}$. Враховуючи політику конфіденційності щодо “childcare reports” (репортажів щодо утримання дитини в сиротинцях чи на всиновленні), позивач у справі Gaskin v. Liverpool City Council програв позови, намагаючись отримати доступ до них: суд чітко заявив про «публічний інтерес» у утриманні цих даних в таємниці - про це у рішенні по справі Гаскіна згадував і Європейський суд з прав людини ${ }^{119}$. Ще через 15 років у справі ex Parte Martin суд постановив, що хоч позивач має право на отримання доступу до даних про свій стан здоров'я за common law (себто, каскад судових прецедентів визнає це право), однак лікарні та інші муніципальні установи мають право самостійно вирішувати, чи буде відповідно «до інтересів пацієнта» надавати йому доступ до документів ${ }^{120}$.

Сучасна практика ЄСПЛ у справах щодо порушення медичної таємниці

Практика Європейського суду з прав людини стосовно різних порушень конфіденційності даних починається з 1970-х років, проте в тематиці медичного права існує не так давно. Так, проблема утримання даних позивача відома ще з справи Леандера (1987р.) $)^{121}$, а доступу до даних (у двох конкретних випадках - з архі-

${ }^{114}$ Garner v. Garner, 36 T.L.R. 196, 196-197 (1920).

${ }^{115}$ In Re D (Infants) [1970] 1 W.L.R. 599, 600-602.

${ }^{116}$ Davidson v. Lloyd Aircraft Services Ltd., [1974] 1 W.L.R. 1042, 1045: Irvin v. Donarghy, [1996] P.I.Q.R. 207, 210.

117 Див. наприклад, Deistung v. South West Metropolitan Regional Hospital Board, [1974] 1 W.L.R. 213, 216-217.

${ }^{118}$ Hunter v. Mann [1974] Q.B. 767, 771-773.

${ }^{119}$ Gaskin v. United Kindgom, [1989] ECHR 13, параграф 15-17.

${ }^{120}$ Regina v. Mid Glamorgan Family Health Services Authority \& Another / Ex Parte Martin, [1995] 1 W.L.R. 110, 116; 119-120.

${ }^{121}$ Leander v. Sweden [1987] 9 E.H.R.R. 433. 
вів спецслужб) - зі справ Сегедштед-Вайберга та Шульца (2006 та 2013 р.р.) ${ }^{122}$; в тому числі - щодо даних про стан здоров'я - зі справи Гаскіна (1989 р. $)^{123}$ та справи M.G. v. United Kingdom ${ }^{124}$. Європейський суд з прав людини стикався $і$ з питанням законності утримання персональних даних у вигляді ДНК в справах Van der Velden $v$. The Netherlands (щодо допустимості розгляду справи, 2006 р.) ${ }^{125}$; $S \&$ Marper v. United Kingdom (2008 p. $)^{126}$ і Khelili c. Suisse (2011 р.) $)^{127}$. До того ж, у них підіймалась тема «права на забуття», адже позивачі воліли отримати рішення суду на видалення чи знищення даних ДНК (Marper) та невірних персональних даних (Khelili) - ці справи автор статті описував в одній з публікацій на тему «права на забуття» стосовно даних про судимість та скоєнні злочинів [33, с. 322-328]. Окремим пунктом можна зазначити і справи Odievre v. France та Godelli v. Italy (2003 та 2012 р.p.), які підіймали тему анонімного батьківства у практиці ЄСПЛ 128 - фактично відродивши з небуття цей концепт - йому у цій статті присвячено окремий підрозділ. Стикався Європейський Суд і з позовами щодо професійних таємниць, зокрема банківських - у справах "Villa Nova" Sommer v. Germany (2017 р.) $)^{131}$. Власне, з цим питанням суд зіткнувся досить пізно, оскільки в міжнародному праві вперше цей аспект виник значно раніше, а саме внаслідок укладення Швейцарією двосторонніх договорів з іншими країнами світу щодо уникнення подвійного оподаткування: в їх положеннях містилися приписи щодо обміну даними для розслідувань економічних злочинів. Федеральний Трибунал Швейцарії, починаючи з 1970 року, не раз стикався з позовами банків, які були проти того, аби їхні документи були надіслані за кордон [34, с. 316-319]. Таким чином, ЄСПЛ відомі справи щодо професійних таємниць, хоча в справах Гаскіна та M.G.v.United Kingdom медична таємниця згадувалася обтічно, хіба що в рамках «публічного інтересу» тримати дані про лікування позивачів слід було «під замком» .

Свропейський суд з прав людини є не єдиним міжнародним судом із прав людини, в рішеннях якого згадується медична таємниця: у справі De La Cruz Flores Vs. Perú, де лікарка, у 1996 р. була засуджена до 20 років ув'язнення буцім-то за допомогу в лікуванні членів терористичної організації, залишаючись ув'язненою ще протягом більш, ніж року після скасування вироку. Суд лише опосередкова-

${ }^{122}$ Segedsted-Wiberg, et al.v. Sweden, [2006] ECHR 697; Szulc v.Poland, [2013] 57 E.H.R.R. 5, 163-167 (обставини справи на вказаних у зносиі сторінках).

${ }^{123}$ Gaskinv.United Kindgom, [1989]12ECHR 36, App. no. 10454/83, Judgment of 7 July 1989.

${ }^{124}$ M.G. v. United Kindgom, 24 September 2002; App. № 39393/98.

${ }^{125}$ Van der Velden $v$. The Netherlands, 7 December 2006, App. № 29514/05.

${ }^{126} S \&$ Marper v. United Kingdom, [2009] Crim LR 355, [2008] ECHR 1581.

${ }^{127}$ Khelili c. Suisse, 18 octobre 2011, App. № 16188/07.

${ }_{128}$ Див. Odievre v. France, [2003] ECHR 86, [2003] F.C.R. 621, App. no. 42326/98, Judgment of 13 Feb. 2003 та Godelli v. Italy, [2012] ECHR 2035, Appl. no. 33783/09, Judgment of 25 September 2012.

${ }^{129}$ B.F.B. Villa-Nova v. Portugal, [2015] ECHR 1049, Judgment of 1 December 2015. 75-98.

${ }^{130}$ GSB v. Switzerland, [2015] ECHR 1122, Judgment of 22 December 2015, див. параграф.

${ }^{131}$ [2017] ECHR 383. 
но звернувся до цього питання в рішенні, хоч і підтвердив, що конфіденційність $€$ винятковим складником правовідносин між лікарем та його пацієнтом. Ця справа була вирішена на користь позивача ${ }^{132}$.

Рішення Європейського суду з прав людини, підібрані у цій статті, цілком охоплюють поняття порушення медичної таємниці, не включаючи справи щодо доступу до стану здоров'я позивача; а справи Odievre v. France та Godelli v Italy представлені в одному з підрозділів нижче, де, зокрема, описано і застосування практики Європейського суду з прав людини Касаційним судом Італії.

Справа Societe Plon v. France є своєрідним рефреном французьких справ щодо порушення медичної таємниці кінця XIX століття, вже описаних у цій статті: Уателета та Консула. Перша з них навіть була побіжно згадана ЄСПЛ у його рішенні по цій справі, хоча згадки про другу, на жаль, не було попри те, що обставини обох вінтажних справ багато в чому вторять цій. Отже, у 1995 р. Societe Plon придбала права на публікацію книги “Le Grand Secret” (1995р.), авторами якої виступив журналіст Гонод та Гублер, лікар президента Франсуа Міттерана. Книга описувала проблеми зі здоров'ям колишнього президента, як він та його лікарі з ними боролися ще з початку 1980-х, Міттеран страждав від раку простати, і йому пророкували швидку смерть, «давши» президенту до трьох років життя. Попри це, він прожив до 1996 р., відбувши президентом два строки (14 років - від 1981 до 1995 р.p.). Невдовзі після смерті Міттерана, книга все ж вийшла, однак буквально за тиждень родина екс-президента подала в суд на видавництво, вигравши (цивільний) позов на першій інстанції, який оштрафував його на 1000 франків та наклав заборону на подальшу дистрибуцію книги. Як Апеляційний суд Парижа, так і Касаційний суд Франції підтвердили рішення, і видавництво вирішило позиватися до Європейського суду з прав людини.

Не пощастило і Гублеру, Гоноду та Орбану, директору видання, проти яких було відкрито і кримінальне провадження: лікар отримав умовний строк ув'язнення строком на чотири місяці, а Гонода і Орбана оштрафували на 30 і 60 тисяч франків відповідно. Апеляцію проти цього рішення всі троє не подавали. В результаті видання Plon та автори книги опинилися у вкрай складному становищі і вирішили позиватись до Європейського суду з прав людини на підставі порушення права на свободу слова (на підставі ст. 10 (1) Європейської Конвенції з прав людини).

Позивачі наголосили, що Міттеран, будучи президентом, неодноразово дозволяв лікарю надавати інформацію щодо свого стану здоров'я, тому, в розуміння «звільнення від конфіденційності», про яке зазначали французькі суди ще понад сто років до цієї справи, президент його від неї, на думку позивачів, «офіційно звільнив». 3 цим представники уряду Франції (відповідачі) не погодилися, наголошуючи на тому, що обсяг інформації про лікування президента та перенесені Міттераном операції був дуже значним (що зі змісту книги, було цілком очевидно). 3 огляду на законодавство і прецедентне право Франції з питань медичної таємниці, суд зробив висновок, що заборона на публікацію та штрафи незаконними не

${ }^{132}$ Corte Interamericana de Derechos Humanos, Caso De La Cruz Flores Vs. Per [2004] IACHR 11, параграф 97-103. 
були. Оцінюючи аспект порушення свободи слова, суд зазначив, що заборона судом на публікацію книги буквально через 10 днів після смерті президента була ще оправданою; також не визнав Європейський суд і цивільні позови родини екс-президента проти видавництва і Гублера як такі, що порушують свободу слова. Проте, на думку ЄСПЛ, подальше продовження заборони на розповсюдження "Le Grand Secret” вже не мало змісту - контекст публікації з часом цілком може мінятися, і час, який пройшов з часу смерті основної дійової особи книги, також має значення. Тому суд визнав подальше продовження заборони дистрибуції порушенням права на свободу слова і вирішив на користь позивачів ${ }^{133}$.

У справі Biriuk v. Lithuania позивачка стала об'єктом публікації у місцевій пресі через свій ВІЛ-позитивний статус: видання "Lietuvos Rytas" написало, що позивачка, тоді 31-річна матір двох дітей, незаміжня, і була ВІЛ-інфікована від місцевих наркоманів, та, мабуть, від її колишнього співмешканця. Вочевидь, цю інформацію (принаймні за матеріалом публікації) підтвердили лікарі госпіталю м. Пасваліс, куди, за даними видання, жінку госпіталізували з туберкульозом, і аналіз крові показав наявність у неї ВІЛ-інфекції. Також видання стверджувало, що у жінки був діагностований СНІД. Позивачка подала позов проти видання до III Регіонального суду в м. Вільнюс, вимагаючи компенсацію в 50 тисяч литів і виграла позов, щоправда суд призначив куди меншу суму - 30 тисяч литів, тому позивачка подала апеляцію, вимагаючи попередню суму: це обернулися лише проти неї, адже апеляційний суд зменшив суму до передбаченої статутом в 10 тисяч литів, пояснюючи рішення тим, що позивачка не змогла довести умисного характеру публікації “Lietuvos Rytas”. Аналогічне рішення прийняв і Верховний Суд Литви. У позові до ЄСПЛ позивачка заявила, що національне (конкретно у цьому випадку - литовське) право не забезпечує адекватного правового захисту від порушення права на приватність. Суд зазначив, що ключовим об’єктом цієї статті був ВІЛ-позитивний статус позивачки, який був інформацією з її приватного життя, i ВІЛ-статус позивачки ніяким чином не міг би становити «суспільного інтересу», а факти щодо способу життя позивачки носили б якоюсь мірою значущий соціальний або науковий інтерес. Суд також звернув увагу, що персонал лікарні міста Пасваліс підтвердив ВІЛ-статус позивачки і зазначив, що національне право [країн-підписантів Конвенції] має забезпечувати збереження такої інформації у режимі конфіденційності. Отже, суд виніс рішення на користь позивачки ${ }^{134}$.

У справі I v. Finland в деякому розумінні «браті-близнюку» справи Estate of Behringer (1991 р.) зі штату Нью Джерсі, США, позивачка 1960 року народження працювала в офтальмологічній клініці. В кінці 1980-х років вона відвідувала цю ж клініку в якості пацієнта, де у неї був виявлений ВІЛ-позитивний статус. Через деякий час вона почала здогадуватися, що колеги знають про її хворобу, а в той час, коли ВІЛ-статус позивачки діагностували, доступ до реєстру пацієнтів мав весь персонал клініки. Що цікаво, довгий час позивачка фігурувала в реєстрах під несправжнім ім'ям. Через декілька років, після завершення роботи в клініці, вона

${ }^{133}$ Editions Plon (Societe) v. France, [2004] ECHR 200, параграф 21-53.

${ }^{134}$ Biriuk v. Lithuania, [2008] ECHR 1528, параграф 5-11; 34-47. 
хотіла встановити, хто саме дізнався про її ВІЛ-позитивний статус і тому звернулася у місцеве губернське управління, яке дало відповідь, що це технічно неможливо дізнатися. Через декілька років позивачка подала в суд на місцеве управління охорони здоров'я, що відповідало за роботу лікарняного реєстру за недбалість в утриманні даних. Щоправда, суд першої інстанції не побачив у діях працівників реєстрів жодних незаконних дій, хоча позивачка внесла висновки омбудсмена з захисту персональних даних, тому позов був програний нею.

Як і суд першої інстанції, апеляційний суд підтвердив - доказів незаконності в діях працівників реєстрів не було. Верховний Суд відмовив у дозволі на апеляцію, і позивачка звернулася в Європейський суд. За даними ЄСПЛ, позови були також програні в силу того, що позивачці не вдалося виявити особу, яка отримувала доступ до картки позивачки. Суд наголосив, що справа відрізняється від ряду подібних рішень ЄСПЛ тим, що позивачка не оскаржувала факту зберігання і утримання даних (як, скажімо, у справах Leander v. Sweden або ж Rotaru v. Romania). Суд визнав предметну юрисдикцію щодо цієї справи і підкреслив, що національне право (в цьому випадку - фінське) має мати механізми захисту даних про стан здоров'я позивача. Суд постановив, що фінське законодавство не забезпечило адекватного режиму захисту даних позивача та вирішив на користь позивачки ${ }^{135}$. Справа I v. Finland, як автором зазначалося вище, є «братом-близнюком» справи Берінгера (1991р.), штат Нью-Джерсі, США. Ї̈̈ обставини є вкрай схожими, за винятком смерті позивача в справі із США. В ній позивач, отоларинголог і пластичний хірург, працював у клініці у м. Прінстон, Нью-Джерсі. У червні 1987 р. він захворів на пневмонію, і його друг відправив його на обстеження у ту ж саму клініку, де він працював. Наступного дня ВІЛ-статус був підтверджений аналізом крові. Молодий лікар боявся, що втратить клієнтів і роботу, проте він дізнався, що факт його ВІЛ-позитивного статусу повідомили лише кільком його друзям та родичам. Досить швидко одужавши, лікар хотів якомога швидше повернутися до роботи, однак він став отримувати безліч дзвінків від друзів-лікарів, жоден із яких не був залучений до лікування, а пацієнти почали відмовлятися від його послуг. Попри погіршення стану свого здоров'я, Берінгер протягом двох років продовжував працювати, не раз будучи госпіталізованим, аж поки не помер. Суд визначив, що лабораторні тести на ВІЛ/СНІД ніяким чином не були захищені (в плані конфіденційності даних), а нездатність клініки забезпечити ї̈ є професійною халатністю - очевидно, що лікар потрапив туди саме як nauiєнm, а отже, його дані мали б бути захищені на рівні з іншими. Суд зазначив, що ця клініка не забезпечила мір по збереженню інформації щодо ВІЛ-статусу, заявивши, що «депозитарієм» медичної таємниці є не тільки лікарі, а і самі лікарні та вирішив на користь позивачів (родичів померлого) визнавши в діях клініки порушення конфіденційності ("breach of confidence") $)^{136}$.

У справі теж піднімалося питання інформованої згоди на виконання операції лікарем з ВІЛ-позитивним статусом та трудова дискримінація на фоні ВІЛ-статусу

${ }^{135}$ I v. Finland, [2008] ECHR 623, параграф 5-17; 35-47.

${ }^{136}$ Estate of Behringer v. Medical Center, 249 N.J. Super. 597, 607-611; 632-642 (1991). 
(адже померлого лікаря миттєво позбавили можливості проводити більшість операцій - що, логічно, могло б негативно позначитися на його кар'єрі). Стосовно цього Верховний Суд штату Нью-Джерсі, підтримуючи правову позицію судів штату Нью-Джерсі в ряді рішень щодо відсутності інформованої згоди на інвазивне лікування, підтримав позицію клініки Прінстона в тому, що усіх пацієнтів необхідно повідомляти, що їх оперуватиме ВІЛ-позитивний лікар ${ }^{137}$.

Сучасна практика ЄСПЛ у справах щодо медичних таємниць та права на анонімні пологи. Розвиток концепиї̈ у праві Франиї, Італії та США

Коротка історія питання. "Право на анонімні пологи" (“l'accouchement sous le secret”) - концепція, яка описує право біологічних батьків залишатися анонімними з умовою того, що їхня дитина, будучи всиновленою, ніколи (або через довгий проміжок часу) не дізнається особистості своїх справжніх батьків. Родоначальником цієї концепції є Франція. Хоча відомості про цю практику, за даними ЄСПЛ у справі Odievre v. France, датуються ще XVII століттям ${ }^{138}$, до наших днів «дожили» справи з першої половини XIX століття. Так, ще на початку 1830-х років, А. Требуше, виокремлюючи ряд питань стосовно медичної таємниці, припускав, що рано чи пізно юристам та судам доведеться зіткнутися 3 наступною ситуацією: чи має лікар надавати дані щодо біологічних батьків дитини? Як вже зазначалося вище, він був схильний вважати, що так [1, с. 277-284]. Однак суди, як виявилося, його позицію не підтримали. Справа в тому, що згідно статей 56-57 ЦК Франції, лікар, який приймав пологи, повинен був у триденний строк повідомити міський реєстр щодо народження дитини з двома свідками, надавши ряд персональних даних дитини та відомості про батьків, в тому числі, їхні імена, місце проживання та професії ${ }^{139}$.

Цікаво, що аналогічна практика існувала і до прийняття «Кодексу Наполеона» ${ }^{140}$. В одній із таких ранніх справ, Королівський суд міста Діжон призначив штраф у 15 франків лікареві, що відмовився надавати дані матері новонародженої дитини в міський реєстр ${ }^{141}$. Витяг рішення суду м. Діжон не надає роз'яснень, на яких підставах відповідач вирішив не надавати дані, однак причина цьому прозаїчна: в ті часи чимало дітей народжувалися у конкубінаті або взагалі від «невідомого» батька, який на момент народження дитини не перебував з її матір'ю

${ }^{137}$ Estate of Behringer v. Medical Center, 249 N.J. Super. 597, 651-654 (1991).

${ }_{138}$ Власне, про це згадує Свропейський Суд у справі Odievre v. France [2003] ECHR 86, [2003] F.C.R. 621, App. no. 42326/98, Judgment of 13 Feb. 2003 (параграф 15). Щоправда, не зовсім зрозуміло, чи описана традиція мала під собою якесь законодавче закріплення. Судячи з усього, це всього-навсього була традиція благодійних установ (якщо їх так можна назвати у той час).

${ }^{139}$ Див. Romieux, Cour. de cass, Cham. Crim., 1 juin 1844, Sirey 1844 I 670, 671.

140 Див. справу Coron c. Testefort-Abel, dit Hamelin, Cour de Cass., 28 mai. 1810, Sirey 1810 I 193, 193-196, 201-202. У цій справі 1810 р., Касаційний суд Франції визначав, чи є свідоцтво про народження достатнім підтвердженням ідентифікації особистості дитини за умови відсутності інших документів. Суд встановив, що далеко не завжди, в тому числі, і конкретно у цій справі.

${ }^{141}$ Clertau c. Ministere Public, Cour de Royale Dijon, 14 aout 1840, 1843 Jour. du. Pal. 737, 737-738. 
в стосунках, тому десятиліттям пізніше Апеляційний суд Анже, обгрунтовуючи свою позицію стосовно допустимості «приховання» даних батьків у справі Шеда$н a$, зазначав, що фігурування даних матері може «скомпрометувати репутацію», якщо дитина народжена не в шлюбі ${ }^{142}$. Такою ж позицією керувався і Касаційний суд Франції у справі Мале (1843р.), стверджуючи, що подібні розголошення можуть сильно «зашкодити честі та майбутньому сімей» ${ }^{143}$.

Так, позиція Касаційного суду Бельгії (надалі - КС Бельгії) у справі Бесселса (див. опис справи нижче) чітко дає зрозуміти, що основною причиною бажання матері, або батьків залишатися анонімними були численні факти народження дітей в осіб, що не перебували в шлюбі ${ }^{144}$. Двома роками раніше Апеляційний суд м. Гент (1853 р.) стверджував, що дитина, інформацію про матір якої намагався приховати лікар (за що проти нього було відкрито кримінальне провадження), була незаконнонародженою ${ }^{145}$. Ст. 55-57 Цивільного кодексу Франції зобов'язували 2 осіб, присутніх при народженні дитини, в триденний термін повідомляти про цей факт до міського реєстру санкцією за невиконання приписів був штраф до 300 франків або ув'язнення на строк до шести місяців за ст. 346 КК Франції ${ }^{146}$.

В першій справі Касаційного суду Франції Мале (1843р.), обвинувачуваний відмовився дати реєстрові дані матері дитини, стверджуючи, що він отримав інформацію «в ході виконання професії, і отже, не має права її розголошувати. Попри відкриття кримінального провадження, лікар зміг виграти справу у прокуратури, яка подала апеляцію та касацію. Касаційний суд сказав, що лікар має право не розголошувати інформацію щодо матері, надаючи притому всю необхідну іншу. Основою для рішення стало те, що «медична таємниця» носить «абсолютний» характер $^{147}$ - вірніше, носила такий характер у праві Франції до початку 20 століття ${ }^{148}$; а отже, суд вирішив, що лікар мав право не розголошувати ці дані.

Аналогічне рішення Касаційний суд Франції прийняв і по справі Рол'є 1 серпня 1844 p. ${ }^{149}$. Цю справу вже неодноразово цитували дослідники в якості доказу історичного підгрунтя існування «права на анонімні пологи» [27, с. 45], хоча з огляду на наведену автором практику судів до справи Ром'є та факти, які наводив Муте (1870 р.), очевидно, що ця справа є далеко не найпершою. Що цікаво, Люк Пасьон (1983 р.), у своєму дослідженні проблеми анонімних пологів, цю справу, як і будь-які інші справи з практики французьких судів, не згадує [25, с. 478-479]. Цей підхід перетерпів ряд змін у плині XIX століття і перетік у свій сучасний варіант - закон 1904 р. закріплював право батьків при всиновленні дитини лишатися анонімними $^{150}$.

${ }^{142}$ Chedanne, Cour d'Appel de Angers, 18 novembre 1850, Dall. Per. 1851 II 20.

${ }^{143}$ Mallet, Cour de Cass., Cham. Crim, 16 septembre 1843, Sirey 1843 I $915,916$.

${ }_{144}$ Bessems c. Le Ministere Public, Cass. 20 juillet 1855, Pas. 1855 I 303, 305-307.

${ }^{145}$ Min. Publ.c. Lecleuse, Cour d'Appel de Gand, BJ 1853.1293, 1294.

${ }_{146}$ Див. роз'яснення Касаційного Суду Франції в справі Mallet, Cour de Cass., Cham.

Crim, 16 septembre 1843, Sirey 1843 I 915, 916; 919.

${ }^{147}$ Там же, с. 916.

${ }^{148}$ Dame Pellerin c. B.et.F., Trib. civ. de Rennes, 12 juin 1903, Dall. Per. 1905 I 321, 321-322.

${ }^{149}$ Romieux, Cour. de cass, Cham. Crim., 1 juin 1844, Sirey 1844 I 670, 671.

${ }^{150}$ Bulletin officiel du Ministère de l'intérieur, 1904 I 273, 282-283. 
Прототип, який був випрацюваний у двох справах Касаційного суду Франції та кількох справах нижчих судових інстанцій закріпив право батьків залишатися анонімними. Що цікаво, нотатки з практики судів стосовно питання право на анонімні пологи наводять дуже цікаві справи, в яких матір, задовго після народження своєї дитини (якщо та була народжена не в шлюбі), все ж, заявляла про свою особу ${ }^{151}$. Щоправда, «французький» підхід не знайшов застосування у бельгійському праві, до того ж, був заперечений Касаційним судом Бельгії: його практика, на щастя, «дожила» до наших днів.

У справі Поля Бесселса бельгійський суд «зарубав» позицію Касаційного суду Франції. Проти Бессемса, відповідача, було відкрито кримінальне провадження за фактом ненадання інформації до міського реєстру щодо матері дитини в муніципалітеті Брехем, Антверпен. Дії обвинувачуваний мотивував лікарською таємницею (тоді - на підставі ст. 378 КК Бельгії); якщо у суді першої інстеанції це спрацювало, то на апеляції рішення було скасовано, і відповідачу присудили штраф у 16 франків. Тому лікар подав касаційну скаргу. КС Бельгії у своєму рішенні фактично озвучив те, що висловив Європейський суд з прав людини 160 років потому у справі Godelli v. Italy ${ }^{152}$ : слід зважити два інтереси: матері, яка воліла б «приховати провину», та дитини, яка через відсутність вказаної особи матері в свідоцтві, може втратити ряд своїх прав (зокрема, і право на спадщину). Суд зазначив, що без належно вказаних даних про особу матері, отже свідоцтво про народження $є$ неповним і вирішив, що це неприпустимо, проводити фактичну сегрегацію новонароджених дітей за ознакою того, чи народжена дитина у шлюбі, чи ні - на що суддя висловився: «[В такому разі] буде достатньо написати [у свідоцтві про народження] - дитина, хлопчик, народився в Брюселі?!» .

Касаційний суд Бельгії вирішив, що, незважаючи на те, чи в шлюбі ця дитина народилася, чи ні, в реєстр обов'язково потрібно вносити дані батьків. Суд ствердив, що подання імен батьків дитини є обов'язком лікаря і не можна не виконати його, посилаючись на його обов'язок тримати таємницю. Суд зазначив, що не можна використовувати медичну таємницю, задля того, аби покривати «злочинні наміри батьків приховати походження [їх дитини]...» ${ }^{153}$. Касаційний суд Бельгії підтвердив рішення апеляційного суду міста Антверпен ${ }^{154}$. До речі, справа КС Бельгії

${ }^{151}$ Louise Sargine c. Lev. et. consorts, Cour d'Appel de Paris, 4 fevrier 1867, Sirey 1867 I 97.

${ }^{152}$ Godelli v. Italy, [2012] E.C.H.R. 374, para. 50; 54-56.

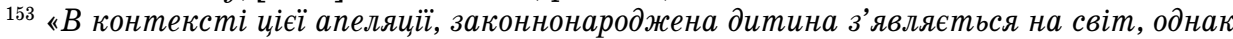
його батько і матір, зі злочинним наміром, хочуть приховати їі походження [...], і рекомендуватимуть акушеру не називати їхніх [ілен], тому людина, присутня при родах, скаже архіваріусу «Імена батька та матері - секрет, який мені заповіли, дитина - законнонароджена, проте я не можу назвати імен батька та матері». Ми не думаємо, що «людині мистеитва» (так часто називали лікарів у судах в 19-20 столітті-Авт.) допустимо робити подібні заяви, $і$ даний приклад, як нам видається, доводить нам зловживання положенням статтею 378 [Кримінального Кодексу], яке ми могли б вчинити [якщо б підтвердили рішення суду першої інстаниії]. [...] Ми ніколи не розумітимемо, що [нормативний зміст] статті 378 [Кримінального Кодексу] зможе перетворити положення статті 346 [Цивільного Кодексу] в «порожню норму»». (Cass. 20 juillet 1855, Pas. 1855 I 303, 308-309, авторський переклад з французької мови).

${ }^{154}$ Bessems c. Le Ministere Public, Cass. 20 juillet 1855, Pas. 1855 I 303, 305-307; 308-309. 
була не першою з цого питання в цій країні: у 1853 р. Апеляційний суд м. Гент у подібній справі засвідчив недопустимість зловживання медичною таємницею, та оштрафувавши лікаря, який намагався приховати особу матері у свідоцтві про народження дитини ${ }^{155}$. Отже, можна констатувати, що в прецедентному праві Бельгії існувала потужна позиція проти «права на анонімні пологи». Цікаво, що французькі справи стосовно анонімних пологів ще в XIX столітті привернули увагу адвоката Муте (1870р.), який прокоментував французький підхід до цього питання і зауважив, що суди Франції стикалися з подібними справами понад десяток разів і не кожного разу рішення вторило справам Мале і Рол'є. Навіть справа з Діжона була не найпершою з цього питання [2, с. 254-256], однак, на жаль, не всі витяги 3 них збереглися до наших днів, через що узагальнити практику принаймні половини з них буде достатньо важко.

Більш сучасний підхід до поняття «анонімних пологів» адаптовано в США, де ще на початку 1970-х років конгреси понад 30 штатів прийняли статути, які дозволяли біологічним батькам залишатися анонімними, а їх нащадки не могли б отримати рішення суду на відкриття їх імен та прізвищ [26, с. 647-і далі]. Але американські законодавці залишали «шпарину»: позивач міг би довести у суді, що має «вагому підставу» отримати доступ до цих даних. Так, у справі зі штату Луїзіана Massey v. Parker (1979 р.), позивач 1945 року народження, будучи всиновленим у віці 2 років, хотів отримати рішення суду щодо відкриття даних про своїх біологічних батьків, воліючи перевірити, чи він володіє спадком. Він також заявив, що хотів фінансово допомогти своїм справжнім батькам, якщо вони цього потребували. Оскільки архіваріус міста Новий Орлеан попередньо дав йому відмову, Массі подав до суду, вигравши позов у суді першої інстанції.

Верховний Суд Луїзіани зазначив, що його бажання дізнатися, чи володіє він спадщиною, є достатньо вагомою причиною для відкриття даних. Суд постановив призначити куратора, який би ознайомився з вмістом документу та перевірив, чи дійсно є «вагомі причини» для їх відкриття, у тому числі, стосовно спадщини $^{156}$. В Луїзіані це був далеко не перший такий позов з аналогічними обставинами справи - у справі Spillman v. Parker (1976), апеляційний суд Луїзіани визнав право позивача на отримання доступу до інформації про його біологічних батьків, адже позивач, як і у справі Massey, хотів дізнатися, чи володіє він спадщиною, заявляючи, що ненадання йому даних щодо його біологічних батьків порушить його спадкові права. Цього суд визнав цілком достатнім, аби надати рішення на отримання доступу ${ }^{157}$. Насправді причина позовів лежить на поверхні: ст. 214 Цивільного кодексу штату Луїзіана ${ }^{158}$, згідно з яким всиновлена дитина зберігає за собою право на спадщину від батьків (будучи при цьому законнонародженим) та інших кровних родичів ${ }^{159}$.

\footnotetext{
${ }^{155}$ Min. Publ.c. Lecleuse, 9 aout 1853, BJ 1853.1294.

${ }^{156}$ Massey v. Parker, La.., 369 So. 2d. 1310, 1313-1315 (1979).

${ }^{157}$ Spillman v. Parker, La., So. 2d. 573, 575-576 (1976).

${ }^{158}$ LSA - CC Art. 214.

${ }^{159}$ Див. також Spillman v. Parker, La., So. 2d. 573, 576 (1976).
} 
У більш пізній справі Kirsch v. Parker позивачка, всиновлена у віці 5 років, спробувала з'ясувати причини її хвороб (наприклад, проблем із нирками і чи можуть вони передатися її дітям, чи є в неї спадкові права на майно її батьків, через що намагалася отримати рішення суду щодо відкриття даних її батьків. Верховний суд Луїзіани прийняв рішення на користь позивача ${ }^{160}$.

Траплялися і позови біологічних батьків проти лікарень за розголошення їх персональних даних їхнім нащадкам, базовані на деліктному праві. У справі Humphers v. First Intestate Bank (штат Орегон, США, 1985 р.). Позивачка Рамона Хамферз розшукувала матір Д. Кастнінг, яка народила доньку у 1959 р. Дівчинка виросла і через 21 рік вирішила розшукати власну матір. Не маючи можливості отримати дані про свою матір, вона розшукала лікаря Хамферс, Гаррі Е. Мекі, який зголосився їй допомогти. Він заявив, що справжніх документів позивачки знайти не міг, однак у силу того, що «давав матері «Діетилстилбестрол»... і для того, аби визначити потенційні наслідки дочці буде необхідно віднайти особу своєї матері». Однак, це виявилося неправдою, і лікар вирішив допомогти жінці таким чином знайти матеріали з медичної карти позивача, який віднайшли і передали Д. Кастнінг у 1982 р. Матір не була рада бачити її і подала в суд на Гаррі Е. Мекі, який на той час помер. Верховний суд штату Орегон підтвердив порушення конфіденційності з боку Гаррі Е. Мекі (його представником виступав First Intestate Bank of Oregon), вирішивши на користь позивача на базі делікту «порушення конфіденційності» (breach of confidence $)^{161}$.

Враховуючи розгляд справи Godelli v. Italy, автор вважає логічним коротко описати і аспекти цього явища в законодавстві і прецедентному праві Італії. Основою для правового регулювання є закон Італії від 4 травня 1983 р. (Legge 4 maggio 1983, n. 184). Рішення Конституційного суду Італії 2005 p. ${ }^{162}$ підтвердило, що право біологічної матері залишатися анонімною, не суперечать Конституції Італії. Доступ до даних про особу біологічних батьків всиновленого позивача (частіше - його матері) був закріплений на підставі рішення суду, до того ж, за низки умов, що могли повністю перекреслити намагання позивача. Власне, неадекватність механізму доступу стало причиною позову проти Італії до ЄСПЛ (нижченаведена справа Godelli v. Italy) і рішення Конституційного суду Італії, який підтвердив неконституційність ряду положень цього закону. Однак, із 2013 р. у законодавство Італії щодо анонімних пологів жодні зміни внесені не були. Тоді, в хід пішло прецедентне право: завдяки рішенням Касаційного суду Італії $2016^{163}$ та $2017^{164}$ р.p., позивачі отримали право на відкриття даних одного з біологічних батьків у випадку його (iï) смерті, а також право отримати рішення суду, за яким сам суд має зв'язатися з біологічною матір'ю позивача та запитати дозволу щодо розголошення $\dddot{1}$ особистості ${ }^{165}$.

\footnotetext{
${ }^{160}$ Kirsch v. Parker, La., 383 So. 2d 384, 385-388 (1980).

${ }^{161}$ Humphers v. First Intestate Bank of Oregon, 696 P. 2d 527, 533-536 (Or. 1985).

${ }^{162}$ Corte di Constituzionale, Sentenza n. 425 del 2005.

${ }^{163}$ Corte di Cassazione, sez. III Civile, sentenza 9 novembre 2016, n. 22838.

${ }^{164}$ Corte di Cassazione, sez. III Civile, sentenza giugno - 29 settembre 2017, n. 1946.

${ }^{165}$ Corte di Cassazione, sez. III Civile, sentenza giugno - 29 settembre 2017, $n .1946$.
} 
У рішенні Касаційного суду 2016 р. матір позивача на момент подачі позову стосовно розголошення даних про її особу, вже померла. Суд у справах неповнолітніх міста Турин, куди він позивався, наголосив, що смерть біологічної матері не є імпліцитом для розголошення даних про її особу, а про залишатись анонімною зі смертю також не зникає. Тепер позивач фактично залишився без права отримати інформацію про особу матері через те, що ставлення матері до розголошення її даних було неможливо отримати за фактол їі слерті. Також позивач волів дізнатися, чи має він право отримати дані про особу своєї матері раніше, ніж 100 років зі створення свідоцтва про народження за фактом її смерті (логічно припустити, що він навряд чи фізично дожив би до цього часу). Суд, враховуючи рішення по справі Godelli v. Italy та рішення Конституційного суду Італії (2013 р.), зазначив, що було би вкрай несправедливо, що позивач, біологічної матері якого вже немає в живих, не може отримати даних про особу своєї матері, однак, інший [гіпотетичний] позивач, в якого біологічна матір жива - зможе, якщо вона на це погодиться. Суд постановив, що позивач має право доступу до даних про особу біологічної матері, вважаючи, що доступ не зашкодить інтересам та репутації третіх осіб ${ }^{166}$. У рішенні від 2017 року Касаційний суд Італії постановив, що за позовом всиновленої особи, суд має право звернутися до матері позивача щодо того, чи вона бажає досі лишатися анонімною, чи воліла б дозволити розголосити дані щодо своєї особистості ${ }^{167}$.

Станом на 2019 рік Європейський суд з прав людини стикався з такими позовами двічі: у справі Odievre v. France (2003 р.) та Godelli v. Italy (2012 р.). Tак, у першому з них (тут і надалі - «справа Одьєвра») позивач, жінка, громадянка Франції 1965 року народження, була залишена батьками при народженні. У кінці 60-х позивач була усиновлена і відтоді носила прізвище прийомних батьків. У віці 30 років позивачка надіслала заяву до Служби соціального захисту дітей Сени (м. Париж), аби отримати там інформацію про біологічних батьків, вірячи, що вона має братів або сестер. Однак усе, що їй вдалося - отримати «анонімні» дані, які були абсолютно беззмістовними для позивача. Позови до суду були програні нею, і їй довелося позиватися до Європейського суду з прав людини. Суд визнав предметну юрисдикцію щодо справи і зауважив, що законодавство, яке дозволяє «анонімні пологи», не $є$ надто розповсюдженим у вропі $^{168}$, хіба що за винятком декількох країн, в числі яких була і Франція, яка і є «батьком» концепції. До того ж, законодавство і прецедентне право Франції дозволяло їй отримати доступ до «анонімних» даних біологічних батьків, що, на думку суду, означало те, що позивачка не була позбавлена її інформаційних прав. Суд не знайшов порушення ст. 8 Конвенції, вирішивши справу на користь відповідача ${ }^{169}$.

У справі Godelli v. Italiy за схожих обставин рішення було протилежним. Автор намагається розібратися, чому позивач у цій справі, літня жінка віком майже 70 ро-

${ }^{166}$ Corte di Cassazione, sez. III Civile, sentenza 9 novembre 2016, n. 22838.

${ }^{167}$ Corte di Cassazione, sez. III Civile, sentenza giugno - 29 settembre 2017, $n .1946$.

168 Див. також коментар Суду у справі Godelli v. Italy, [2012] E.C.H.R. 347, параграф. 28-31.

${ }^{169}$ Odievre v. France, [2003] F.C.R. 621, параграф. 15-і далі. 
ків, вирішила розшукати своїх предків. Вона народилася у 1943 р. і була всиновлена у віці 6 років. Проживаючи у селищі, позивачка познайомилася з дівчиною, яка, як виявилося, також була всиновленою, однак їх батьки постійно намагалися не допускати контактів між дітьми, та ніколи не наводили інформації про батьків позивачки. 3 того часу минуло півстоліття, і вже 63-річна позивачка звернулася до міського реєстру з заявою отримати доступ до даних про їі справжніх батьків, отримавши відмову. Позов до суду першої інстанції та апеляцію позивачка програла: апеляційний суд зазначив, що за положеннями Цивільного кодексу Італії відкриття таких документів можливе за двох умов: 1) за рішенням суду в справах неповнолітніх, за умови того, якщо вік позивача становить 25 років та наявні «медичні» ${ }^{170}$ причини для того, аби дати рішення ${ }^{171} ; 2$ ) доступ надається лікареві.

Тут також варто додати, в Італії доступ всиновленої особи до записаних даних біологічної матері без її згоди теж не допускається ${ }^{172}$. Суд, як і в справі Odievre v. France, підтвердив, що практика «анонімних пологів» є рідкістю в законодавстві і прецедентному праві країн Континентальної Європи, але не є містифікацією ${ }^{173}$. У позовній заяві до ЄСПЛ позивачка зазначила, що не змогла добитися отримання «анонімних» даних, вбачаючи в цьому порушення Італією ст. 8 (1) Європейської Конвенції з прав людини. Суд зазначив, що слід правильно зважувати баланс між конкуруючими приватними інтересами - зі сторони нащадків та зі сторони батьків (саме на цьому, вирішуючи справу Бессемса, наголошував КС Бельгії у середині XIX століття ${ }^{174}$. Перевага була на стороні позивача після справи Godelli та визнання положень закону 1983 р. Конституційним Судом Італії. Такої ж думки був і Касаційний суд Італії у своїй сучасній практиці $\left.{ }^{175}\right)$. Якщо порівняти обставини справи зі справою Odievre v. France, то якщо в першій - позивач безперешкодно отримав доступ до «анонімних" даних обох своїх батьків, то вищевказаного не відбулося у справі Godelli ${ }^{176}$. Суд зазначив, що попри вік позивачки (їй було майже 70 років на момент винесення рішення суду по справі), вона бажала виявити свій родовід. Бажання позивача, на думку суду, не зникає з віком.

Право Італії, на відміну від франиузького, не забезпечило необхідного балансу між наданням можливості надати доступ принайлні до «анонілних даних». Тому суд вирішив на користь позивачки ${ }^{177}$. Застосування рішення Європейського

170 Чим є, власне, ці «медичні» причини, з тексту рішення суду не зовсім зрозуміло. Втім, обставини справи Конституційного Суду Італії 2013 року (Corte di Constituzione, Sentenza $n$. $278 \mathrm{del} 2013)$ дозволяють припустити, що позивач, який, можливо, є носієм ряду спадкових захворювань, воліє дізнатися інформацію про своїх біологічних батьків, аби перевірити, чи існували у їх батьків ці захворювання. Аналогічна практика судів існує і в США: Kirsch v. Parker, La., 383 So. 2d 384, 385-388 (1980).

${ }^{171}$ Godelli v. Italy, [2012] E.C.H.R. 347, параграф. 7-15 (обставини справи).

172 Див. Corte di Constituzione, Sentenza n. 278 del 2013; Trib. Milano, Sentenzia no. 11475/15 del 14 Ottobre 2015;

${ }^{173}$ Godelli v. Italy, [2012] E.C.H.R. 374, параграф. 18-23; 28-31 (стосовно аналізу італійського законодавства з цього питання).

${ }^{174}$ Bessems c. Le Ministere Public, Cass. 20 juillet 1855, Pas. 1855 I 303, 308.

${ }^{175}$ Corte di Cassazione, sez. III Civile, sentenza 15 giugno - 29 settembre 2017, n. 22838.

${ }^{176}$ Див. Odievre v. France, [2003] F.C.R. 621, параграф. 12.

${ }^{177}$ Godelli v. Italy, [2012] E.C.H.R. 374, параграф. 50; 54-56; 57-59. 
cyдy по справі Godelli v. Italy відображене в рішенні Конституційного суду Італії 2013 p. ${ }^{178}$. У цій справі суд Катандзаро у справах неповнолітніх підняв питання щодо конституційності ряду положень закону 1983 р., які фактично виключали можливість надання позивачу даних щодо його (іï) біологічних батьків. Подання суду Катандзаро виникло з позову жінки 1963 року народження, яка про власне всиновлення дізналася в дорослому віці під час процедури розлучення з чоловіком та бажала отримати інформацію про походження, вважаючи, що захворювання, на які позивачка страждала, вочевидь, мали спадковий характер. Позивачка не отримала ніякого доступу, адже її матір не хотіла, аби інформацію про її особу розголошували: виходить, що її право на отримання інформації анулювалося небажанням біологічних батьків, і це передбачав закон: за ст. 28 (7) закону від 4 травня 1983 р. виключається можливість надання всиновленій особі доступу до інформації про його походження без попередньої перевірки збереження волі матері в небажанні бути вказаною, як біологічна матір дитини.

Постає питання: невже ж позивача наділено «порожнім» правом за умови небажання матері, чи фактом того, що дані матері першопочатково не були записані у свідоцтві? Конституційний Суд, взявши до уваги рішення ЄСПЛ по справі Godelli v. Italy, зазначив, що положення закону 1983 р. не надають можливості матері у майбутньому підтвердити особу, якщо вона цього забажає, а також - унеможливить отримання інформації щодо стану здоров'я предків позивача, що може мати необхідність для профілактики спадкових захворювань. Суд підтвердив, що законодавство Італії в паритеті між правами батьків та нащадків схиляється на користь останнього, відповідно до якого шкода, завдана матері від розголошення іï даних (якщо ці дані записувалися) є більшою, ніж шкода, завдана позивачеві, який не зміг (і не зможе) дізнатися про власне походження.

Конституційний суд Італії дійшов висновку, що в силу того, що законодавство Італії не надає можливість доступу не те, що до повних, а навіть до «анонімних" даних (напротивагу до французького законодавства), що дуже чітко випливало з рішення ЄСПЛ по справі Odievre, вказана стаття закону є неконституційною ${ }^{179}$.

Висновки. Стаття надає компаративний аналіз практики судів Європи, Англії, США та Європейського суду з прав людини як в історичному, так і сучасному аспекті. Будуючи таку роботу, автор намагався в першу чергу акцентувати увагу не на теоретико-правових чи етичних аспектах практики судів XIX - XX століття, в якій були випрацювані принципи прийняття рішень у справах стосовно процесуального та позапроцесуального розголошення медичної таємниці.

Автор провів аналіз країн континентального (Франція, Бельгія, Німеччина) та англо-саксонського права (США та Англія) та здійснив систематизацію ряду рішень Європейського суду з прав людини з цієї тематики. Попри те, що практика ЄСПЛ не є надто значною, в ній вже фігурують справи (наприклад, I v. Finland), які відкривають цілком нову проблему: захист конфіденційності ВІЛ-статусу не пацієнта, а працівника лікарні, що рефреном йде 3 дев'яностих, з американ-

${ }^{178}$ Corte di Constituzionale, Sentenza n. 278 del 2013.

${ }^{179}$ Corte di Constituzione, Sentenza n. 278 del 2013. 
ської справи Беррінгера (1991р.); інші ж справи (наприклад, Societe Plon v. France) є більш «класичними» та висвітлюють позови щодо розголошення медичної таємниці в пресі та науковій літературі. Опис та належне узагальнення практики судів обраних країн у сфері медичної таємниці - як історичної, так і сучасної - показує, що суди як у континентальній, так і англо-саксонській системі права по-різному інтерпретували це поняття, по-різному оцінювали припустимість ї̈̈ законного розголошення на підставі або законодавства, або прецедентного права - найбільшої уваги цьому приділяли американські суди.

Аналіз історичної судової практики показав, що в дійсності, правова природа медичної таємниці лежить не тільки в практиці судів, а і в медичній етиці, яка, подібно до традиції, супроводжує професію лікарів вже не одне століття, що неодноразово підтверджували відмови лікарів свідчити щодо стану здоров’я своїх пацієнтів на цивільному та кримінальному процесі.

Іншою, цілком сучасною (скоріше, «відродженою з небуття») темою є право батьків на анонімність - протистояння інтересів між збереженням батьками їх анонімності, а дітьми - правом на отримання інформації про своїх батьків. Хоча рішення ЄСПЛ по справах Odievre v. France та Godelli v. Italy показали, що компромісним варіантом (принаймні як для Європейського суду) є «анонімні дані» батьків. Однак, таку позицію не розділяли італійські та американські суди. Так, у США суди в штаті Луїзіана в 1970-х надавали рішення щодо розкриття цих даних, зокрема, через особливості цивільного законодавства, яке дозволяло зберігати право на спадщину всиновленій особі, чим деякі громадяни не могли не скористатися. В Італії, імплементуючи рішення по справі Godelli, суди також поступово стали відходити від концепції абсолютної анонімності, хоча і не за варіантом ЄСПЛ.

У той же час, існує чимало проблем у галузі медичного права, які наразі не практично не висвітлені в практиці Європейського суду з прав людини, тому автор сподівається, що ця тема набуде подальшого дослідження, обов'язково ставши в нагоді як науковцям, так і практикуючим юристам.

\section{Jimepamypa}

1. Adolphe Trebuchet, Jurisprudence de la medicine, de la chirurgie et de la pharmacie en France, Paris, Librairie de L'Academie Royale de Medecine, Londres, Meme Maison 219 Regent Street, 1834.

2. Charles Muteau, Du Secret Professionnel: Traite Theoretique et Practique, Paris, Marescq Aine, Libraire Editeur, 1870.

3. Chaevau Adolphe, Faustin Helie, Theorie du Code Penal, Tome Cinquintiene. Paris, Imprimerie et Librairie Generale de Jurisprudence. Place Dauphine, 27, 1872.

4. Giuseppe Ziino, Compendio di medicina legale e giurisprudenza medica: secondo le leggi dello stato, Napoli, Libreria nella R. Universita, 1882.

5. American and English Encyclopedia of Law (ed. by. J. H. Merrill), Volume XIX (19), Edward Thompson Co., Northport Long Island N.Y., 1892.

6. Federico Puga Borne, Compendio de Medecine Legal: Adaptado a la Legislation Chilena, Imprenta Cervantes, Santiago de Chile, 1896.

7. Paule Brouardel, La Responsibilite Medical, Paris, Librairie J.B. Bailliere et Pils, 1898.

8. Andre Fazembat, Responsibilite legale des Medecins Traitants, Paris, Bailliere et Fils, 1903.

9. Bulletine de la Societe de Medecine legale de France, 38 Annee, Paris, Librairie de la 8. Cour de Cassation, 1907. 
10. Anfosso Luigi, La legislazione italiana sui manicomi e sugli alienati : commento alla legge 14 febbraio 1904, n. 36 ed al regolamento approvato con R. decreto 5 marzo 1905, n. 158, Unione Tipographico-Editrice Torinese, Torino, Corso Rafaello 28, 1907.

11. Albert Moll, Ärztliche Ethik: die Pflichten des Arztes in allen Beziehungen seiner Thätigkeit, Stuttgart, Verlag von Ferdinand Enke, 1902.

12. Clinton DeWitt, Medical Ethics and the Law: The Conflict between Dual Allegiances, 5 W. Res. L. Rev. 5 (1953).

13. Samuel Friedman, Medical Privilege, 32.1 Canadian Bar Rev. 1 (1954).

14. Clinton DeWitt, Privileged Communications between Physician and Patient, 10 Wes. Res. L. Rev. 488 (1959).

15. Robert. B. Dunsmore, Hospital Records as Evidence, 8 Cleveland-Marshall L. Rev. 459 (1959).

16. Rignal W. Baldwin, Confidentiality Between Physician and Patient, 22 Md. L. Rev. 181 (1962).

17. David Vaver, Medical Privilege in New Zealand, 6 Auckland L. Rev. 63 (1966).

18. Charles J. Roedersheimer, Action for Breach of Medical Secrecy Outside the Courtroom, 36 U. Cin. L. Rev. 103 (1967).

19. W. K. Bernfeld, Medical secrecy, 3 Cambr. L. Rev. 11 (1972).

20. A. Hopper, The Medical Man's Fiduciary Duty, 7 Law Teacher 73 (1973).

21. Alec Samuels, The Duty of the Doctor to Respect the Confidence of the Patient, 20 Med. Sci. Law. 58 (1980).

22. D. W. Shuman, The Origins of the Physician-Patient Privilege and Professional Secret, 39 Sw. L.J. 661 (1985).

23. Erwin Deutsch, Das Persönlichkeitsrecht des Patienten, 192 Bd. H. (Archiv für die civilistische Praxis) 161 (1992).

24. Angus McLaren, Privileged Communications: Medical Confidentiality in Late Victorian Britain, 37 Medical History 129 (1993).

25. Louis Waller, Secrets Revealed: The Limits of Medical Confidence, 9 J. Contemp. Health L. \& Pol'y 183 (1993).

26. Luc Passion, Législation et prophylaxie de l'abandon à Paris au début du XXème siècle, Histoire, économie \& société (Année 1983), 475.

27. Anne E. Crane, The Right to Know Versus the Right to Privacy, 1986 A.S. Am. Law 645, 647 etc. (1986).

28. Marcela Iacub, Naître sous X, Savoirs et clinique 2004/1 (№ 4).

29. Anatoliy A. Lytvynenko, Common Law Right to Access to Medical Records: The Commonwealth and European Court of Human Rights Practice, $7^{\text {th }}$ International Conference of PhD students and Young Researchers: Law 2.0 - New Methods, New Laws (Vilnius, Lithuania) (2019).

30. Jean Domat, Le Droit Publique et Legum Delectus, Paris, Tome Second, 1777.

31. Frederick E. Birkenhead, Famous Trials of History, Garden City (New York), Garden City Publishing Co., Inc.; The Star Series, 1926.

32. Gelbert Geis \& Ivan Bunn, Sir Thomas Browne and Witchcraft: a cautionary tale for contemporary law and psychiatry, 4 (1-2). Int'l. J. Law \& Psychiatry 1 (1981).

33. Blewett Lee, Psychic Phenomena and the Law, 24 Harv. L. Rev. 621 (1921).

34. Anatoliy A. Lytvynenko, Data Privacy and Banking Secrecy: Topical Issues in Commonwealth, Continental Europe and International Jurisprudence, 5.3 Athens Journal of Law 303 (2019). 


\begin{abstract}
Анотація
Литвиненко А. А. Захист персональних даних у сфері медичної таємниці: історична та сучасна практика судів США, Свропейського суду з прав людини та деяких країн континентальної Свропи. Стаття.

Стаття присвячена розгляду судової практики ЄСПЛ, Сполучених Штатів, Америки, Англії та декількох країн Континентальної Європи у сфері медичної таємниці, як одного з численних аспектів захисту конфіденційності даних позивача, даних про його стан здоров'я, історію хвороби та суміжну інформацію. Медична таємниця є багатогранним поняттям, оскільки включає в себе варіацію позовів, які виникають як у разі розголошення даних про стан здоров'я позивача, так і стосовно допустимості використання свідчень лікарів у цивільному та кримінальному процесі в якості доказів, що часто обмежується законодавством та прецедентним правом як у англо-саксонській, так і континентальній правовій сім’ї.

Вартує уваги і дослідження історичного розвитку цього поняття в практиці судів, яка є порівняно незначною на фоні інших аспектів медичного права, як, скажімо, медична халатність, або інформована згода на інвазивне лікування; тому, автор у статті наводить ряд вінтажних судових процесів, що зіграли чималу роль у формуванні сучасної практики судів у сфері медичної таємниці. Впродовж останніх двох десятиліть, Європейський суд з прав людини виніс ряд рішень по справах, що стосуються розголошення даних про стан здоров'я позивача третім особам або в ЗМІ чи науковій літературі (Biriuk v. Lithuania та Societe Plon v. France), допустимості використання цих даних в якості доказів на кримінальному процесі (рішення по справі Z v. Finland 1995 р.), а також вторинних концептів медичної таємниці, або "l'accouchement sous le secret" (право на анонімні пологи), відображенням яких є рішення Європейського Суду у рішеннях по справах Odievre v. France (2003 р.) та Godelli v. Italy (2012 p.). Toмy виникає питання вивчення практики цих судів та їі систематизації, а також вивчення її історичного розвитку, що і спробував описати автор у статті.

Окрім цього, у статті систематизовано визначення «даних про стан здоров'я» позивача та опис і розвиток концепції «права на анонімні пологи», як в історичній, так і в сучасній практиці судів кінця XX та початку XXI століття.

Ключові слова: медична таємниця, персональні дані, медична халатність, медичне право, право на недоторканність особистого життя, “l’accouchement sous le secret”.
\end{abstract}

\title{
Summary
}

Lytvynenko A.A. Data privacy in the sphere of medical confidentiality: the historical and contemporary case-law of the United States, the European Court of Human Rights and selected Continental Europe states. - Article.

The abovegiven paper is devoted to medical confidentiality jurisprudence of the European Court of Human Rights, United States of America as well as selected Contintental Europe states. Medical secrecy is one of various plaintiff's data privacy aspects - namely, his data concerning the state of health, the ailment history as well as related information. Medical confidentiality is quite a multidimensional concept as it involves a variety of lawsuits which arise from plaintiff's health data revelations or concerning the admissibility of physician's testimony (so called patient-physician privilege) in civil and criminal actions as evidence, which is frequently constrained by legislation and jurisprudence in both continental and common law legal systems.

The historical traces of medical confidentiality in case law are of particular value as the amount of existing jurisprudence is quite little in comparison with other aspects of medical malpractice law, as, for instance, medical negligence or informed consent for invasive treatment. For the aforegiven reason, the author gives a description of a number of vintage trials which played a substantial role in the formation of the contemporary medical confidentiality jurisprudence. The European Court of Human Rights has adjudicated several decisions concerning revelations of plaintiff's health data in the mass-media, or scientific literature (Biriuk v. Lithuania and Societe Plon v. France), the admissibility of using the plaintiff's health data at a criminal trial (Z v. Finland trial), and a secondary medical confidentiality concept "l'accouchement sous le secret" (or "anonymous childbirth"), which are reflected by the European Court's judgments in Odievre v. France (2003) and Godelli v. Italy (2012).

Thus, there is a necessity to investigate on the said courts' jurisprudence and to systemize it, and to explore it's historical background. So, the author strives to cover the announced issues in the paper. Apart from the abovestated, the article embraces such aspects, as the systematization of the definition of "health data", as well as the description and the evolvement of "anonymous childbirth" concept in the historical and modern case law of late XX - and early XXI century.

Key words: medical confidentiality, personal data, medical malpractice, medical law, right to privacy, "l'accouchement sous le secret". 